medRxiv preprint doi: https://doi.org/10.1101/2020.10.07.20208587; this version posted March 23, 2021. The copyright holder for this preprint (which was not certified by peer review) is the author/funder, who has granted medRxiv a license to display the preprint in perpetuity.

It is made available under a CC-BY 4.0 International license .

\title{
Remote home monitoring (virtual wards) during the COVID-19 pandemic: a systematic review
}

Cecilia Vindrola-Padros (0000-0001-7859-1646), Kelly E Singh (0000-0002-4513-1026), Manbinder S Sidhu (0000-0001-5663-107X), Theo Georghiou (0000-0001-9532-876X), Chris Sherlaw-Johnson (0000-0002-4851-6060), Sonila M Tomini (0000-0002-4241-2121), Matthew Inada-Kim (0000-0001-6026-2246), Karen Kirkham, Allison Streetly (0000-00027588-9276), Naomi J Fulop (0000-0001-5306-6140)

Cecilia Vindrola-Padros, Senior Research Fellow, Department of Targeted Intervention, University College London (UCL), Charles Bell House, 43-45 Foley Street, London, W1W 7TY, United Kingdom, c.vindrola@ucl.ac.uk.

Kelly Elizabeth Singh, Evaluation Fellow, Health Services Management Centre, School of Social Policy, University of Birmingham, Park House, University of Birmingham, Edgbaston, Birmingham, B15 2RT, UK, k.e.singh@bham.ac.uk.

Manbinder S Sidhu, Research Fellow, Health Services Management Centre, School of Social Policy, University of Birmingham, Park House, University of Birmingham, Edgbaston, Birmingham, B15 2RT, UK, m.s.sidhu@bham.ac.uk.

Theo Georghiou, Senior Fellow, Nuffield Trust, 59 New Cavendish Street, London, W1G 7LP, UK, theo.georghiou@nuffieldtrust.org.uk.

Chris Sherlaw-Johnson, Senior Fellow, Nuffield Trust, 59 New Cavendish Street, London, W1G 7LP, UK, chris.sherlaw-johnson@nuffieldtrust.org.uk

Sonila M Tomini, Research Fellow, UCL Department of Applied Health Research, University College London, Gower Street London, WC1E 6BT, UK, s.tomini@ucl.ac.uk

Matthew Inada-Kim, Consultant Acute Physician, Hampshire Hospitals NHS Foundation Trust, Clinical Director Patient Safety \& Digital, Wessex Academic Health \& Science Network, National COVID Clinical Reference groups- Primary care, Secondary care, Care homes, National Clinical Lead Deterioration \& National Specialist Advisor Sepsis, NHS England and NHS Improvement, McGill ward, Royal Hampshire County Hospital, Romsey Road, Winchester SO21 1QW, UK, matthew.inada-kim@nhs.net.

Karen Kirkham, General Practitioner NHS Dorset, Integrated Care System Clinical Lead, NHSE/I Senior Medical Advisor Primary Care Transformation, Dorset CCG, Vespasian House, Barrack Rd, Dorchester, Dorset DT1 7TG, UK, Karen.kirkham@dorsetccg.nhs.uk.

Allison Streetly, Senior Lecturer in Public Health Kings College London, Department of Population Health Sciences Faculty of Life Sciences \& Medicine King's College London SE1 1UL, UK and Deputy National Lead Healthcare Public Health, Public Health England 133-155 Waterloo Rd, London SE1 8UG, UK, allison.streetly@phe.gov.uk

Naomi J Fulop, Professor of Health Care Organisation and Management, UCL Department of Applied Health Research, University College London, Gower Street London WC1E 6BT, UK, n.fulop@ucl.ac.uk 
medRxiv preprint doi: https://doi.org/10.1101/2020.10.07.20208587; this version posted March 23, 2021. The copyright holder for this preprint (which was not certified by peer review) is the author/funder, who has granted medRxiv a license to display the preprint in It is made available under a CC-BY 4.0 International license .

\section{Corresponding author:}

\section{Dr Cecilia Vindrola}

Senior Research Fellow

Department of Targeted Intervention

University College London (UCL)

Charles Bell House

43-45 Foley Street

London

W1W 7TY

UK

c.vindrola@ucl.ac.uk 
medRxiv preprint doi: https://doi.org/10.1101/2020.10.07.20208587; this version posted March 23, 2021. The copyright holder for this preprint (which was not certified by peer review) is the author/funder, who has granted medRxiv a license to display the preprint in perpetuity.

It is made available under a CC-BY 4.0 International license .

\begin{abstract}
Objectives: The aim of this review was to analyse the implementation and impact of remote home monitoring models (virtual wards) during COVID-19, identifying their main

components, processes of implementation, target patient populations, impact on outcomes, costs and lessons learnt.

Design: A rapid systematic review to capture an evolving evidence base. We used the Preferred Reporting Items for Systematic Reviews and Meta-Analysis (PRISMA) statement. Setting: The review included models led by primary and secondary care across seven countries.
\end{abstract}

Participants: 27 articles were included in the review.

Main outcome measures: Impact of remote home monitoring on virtual length of stay, escalation, emergency department attendance/reattendance, admission/readmission and mortality.

Results: The aim of the models was to maintain patients safe in the right setting. Most models were led by secondary care and confirmation of COVID-19 was not required (in most cases). Monitoring was carried via online platforms, paper-based systems with telephone calls or (less frequently) through wearable sensors. Models based on phone calls were considered more inclusive. Patient/carer training was identified as a determining factor of success. We could not reach substantive conclusions regarding patient safety and the identification of early deterioration due to lack of standardised reporting and missing data. Economic analysis was not reported for most of the models and did not go beyond reporting resources used and the amount spent per patient monitored.

Conclusions: Future research should focus on staff and patient experiences of care and inequalities in patients' access to care. Attention needs to be paid to the cost-effectiveness of the models and their sustainability, evaluation of their impact on patient outcomes by using comparators, and the use of risk-stratification tools.

Protocol registration: The review protocol was published on PROSPERO (CRD: 42020202888).

Keywords: remote home monitoring, virtual wards, COVID-19, silent hypoxia, rapid systematic review

\title{
RESEARCH IN CONTEXT
}

\section{Evidence before this study}

Remote home monitoring models for other conditions have been studied, but their adaptation to monitor COVID-19 patients and the analysis of their implementation constitute gaps in research.

\section{Added value of this study}

The review covers a wide range of remote home monitoring models (pre-hospital as well as step-down wards) implemented in primary and secondary care sectors in eight countries and focuses on their implementation and impact on outcomes (including costs).

\section{Implications of all the available evidence}

The review provides a rapid overview of an emerging evidence base that can be used to inform changes in policy and practice regarding the home monitoring of patients during COVID-19. Attention needs to be paid to the cost-effectiveness of the models and their sustainability, evaluation of their impact on patient outcomes by using comparators, and the use of risk-stratification tools. 
medRxiv preprint doi: https://doi.org/10.1101/2020.10.07.20208587; this version posted March 23, 2021. The copyright holder for this preprint (which was not certified by peer review) is the author/funder, who has granted medRxiv a license to display the preprint in perpetuity.

It is made available under a CC-BY 4.0 International license .

\section{INTRODUCTION}

COVID-19 has rapidly spread across the world, leading to high rates of mortality and unprecedented pressure on healthcare systems. Delays in the presentation of patients with COVID-19 has led to patients arriving as emergencies with very low oxygen saturation, often without accompanying breathlessness ('silent hypoxia') ${ }^{1}$. These delayed presentations of severe COVID-19 lead to extended hospital admissions for patients, often requiring invasive treatment and potential admission to intensive care units (ICU) or death ${ }^{2}$. Remote home monitoring models (sometimes referred to as 'virtual wards') have been established to: 1) avoid unnecessary hospital admissions (appropriate care at the appropriate place), and 2) escalate cases of deterioration at an earlier stage to avoid invasive ventilation and ICU admission ${ }^{3}$. Some of these models have integrated the use of pulse oximetry to monitor oxygen levels and identify and treat cases of 'silent hypoxia'?

Remote home monitoring models have been implemented in the US, Australia, Canada, the Netherlands, Ireland, China and UK, with some variation in the frequency of patient monitoring, modality (a combination of telephone or video calls and use of applications or online portals), patient admission criteria, staffing models used for patient monitoring and level of clinical oversight, and use of pulse oximetry ${ }^{4-8}$.

There is a paucity of published literature on the models of care developed to implement remote home monitoring across different healthcare contexts during the COVID-19 pandemic, the experiences of staff implementing these models and patients receiving care, the use of data for monitoring progress, resources required, as well as the impact of these models on clinical, process and economic outcomes. The aim of this review was to address these gaps by identifying the nature and scale of remote home monitoring models implemented during COVID-19, their main components, processes of implementation, target patient populations and lessons learned. We sought to analyse and interpret evaluations of these models and their outcomes.

\section{METHODS}

\section{Design}

We followed the review method proposed by Tricco et al. ${ }^{9}$. The rapid review method follows a systematic review approach but proposes adaptations to some of the steps to reduce the amount of time required to carry out the review. We used a large multidisciplinary team to review abstracts and full texts, and extract data; in lieu of dual screening and selection, a percentage of excluded articles was reviewed by a second reviewer, and software was used for data extraction and synthesis ${ }^{9}$.

We used the Preferred Reporting Items for Systematic Reviews and Meta-Analysis (PRISMA) statement ${ }^{10}$ to guide the reporting of the methods and findings. The review protocol was registered with PROSPERO (CRD: 42020202888, registered 6 August 2020).

\section{Research questions}

The review sought to answer the following questions:

1. What are the aims and designs of remote home monitoring models?

2. What are the main stages involved in delivering remote home monitoring for COVID-19?

3. Which patient populations are considered appropriate for remote monitoring?

4. How is patient deterioration determined and flagged?

5. What are the expected outcomes of implementing remote home monitoring?

6. What is their impact on outcomes and costs?

7. What are the benefits and limitations of implementing these models? 
medRxiv preprint doi: https://doi.org/10.1101/2020.10.07.20208587; this version posted March 23, 2021. The copyright holder for this preprint (which was not certified by peer review) is the author/funder, who has granted medRxiv a license to display the preprint in perpetuity.

It is made available under a CC-BY 4.0 International license .

\section{Search strategy}

We used a phased search approach ${ }^{9}$. We carried out a series of search phases where we gradually added search terms based on the keywords used in the literature we identified. Appendix 1 includes the strategies used for each search phase, including the final search strategy. We searched for literature indexed in the following databases: MEDLINE, CINAHL PLUS, EMBASE, TRIP, medRxiv and Web of Science. Initial searches were carried out by CV on 9 July 2020 and updated on 21 August 2020, 21 September 2020 and 5 February 2021. Results were combined into Mendeley and duplicates were removed. The reference lists of included articles were manually screened to identify additional relevant publications.

\section{Study selection, inclusion and exclusion criteria}

One researcher (CVP) screened the articles in the title phase, and additional researchers (KS) cross-checked exclusions in the abstract and full-text phases (KS, MS). Disagreements were discussed until consensus was reached. The inclusion criteria used for study selection was: 1) focus on the monitoring of confirmed or suspected patients with COVID-19), 2) focus on pre-hospital monitoring, monitoring after Emergency Department (ED) presentation and step-down wards for early discharge, 3 ) focus on monitoring at home (excluding monitoring done while the patient is in healthcare facilities), and 4) published in English. Due to the rapidly expanding evidence-base on COVID-19, we included a wide range of publications (i.e. feature articles, descriptions of services, preprints) and did not limit the selection to evaluations of remote home monitoring.

\section{Data extraction and management}

The included articles were analysed using a data extraction form developed in REDCap (Research Electronic Data Capture) that extracted data on: the design and general characteristics of the model, patient populations, main reported process and clinical outcomes and its potential economic impact. The form was developed after the initial screening of full-text articles. It was then piloted independently by two researchers using a random sample of five articles (CV and KS). Disagreements were discussed until consensus was reached. The data extraction form was finalised based on the findings from the pilot. Data extraction was cross-checked by three researchers (TG, CSJ and ST).

\section{Data synthesis}

Data were exported from REDCap and the main article characteristics were synthesised. The information entered in free text boxes was exported from REDCap and analysed using framework analysis ${ }^{11}$. The initial categories for the framework were informed by our research questions but we were also sensitive to topics emerging from the data.

\section{Quality assessment}

Due to the descriptive nature of the articles and limited data in relation to study design, we did not assess the quality of the studies.

\section{RESULTS}

The initial search yielded 902 articles (Figure 1). These were screened based on the title and abstract and type of article, resulting in 155 articles for full-text review. Full-text review of these articles led to 11 articles that met the inclusion criteria (reasons for exclusion can be found in Figure 1). Three additional articles were identified by reviewing the bibliography, two articles were identified in an updated search carried out on 21 September 2020, and eleven articles were added in an updated search carried out on 5 February 2021, ultimately leading to 27 articles included in the review. We excluded articles that focused on monitoring that took place within hospital settings (i.e. ICU) or for other non-COVID-19 related conditions. 
medRxiv preprint doi: https://doi.org/10.1101/2020.10.07.20208587; this version posted March 23, 2021. The copyright holder for this preprint (which was not certified by peer review) is the author/funder, who has granted medRxiv a license to display the preprint in perpetuity.

It is made available under a CC-BY 4.0 International license .

Figure 1. Study selection process

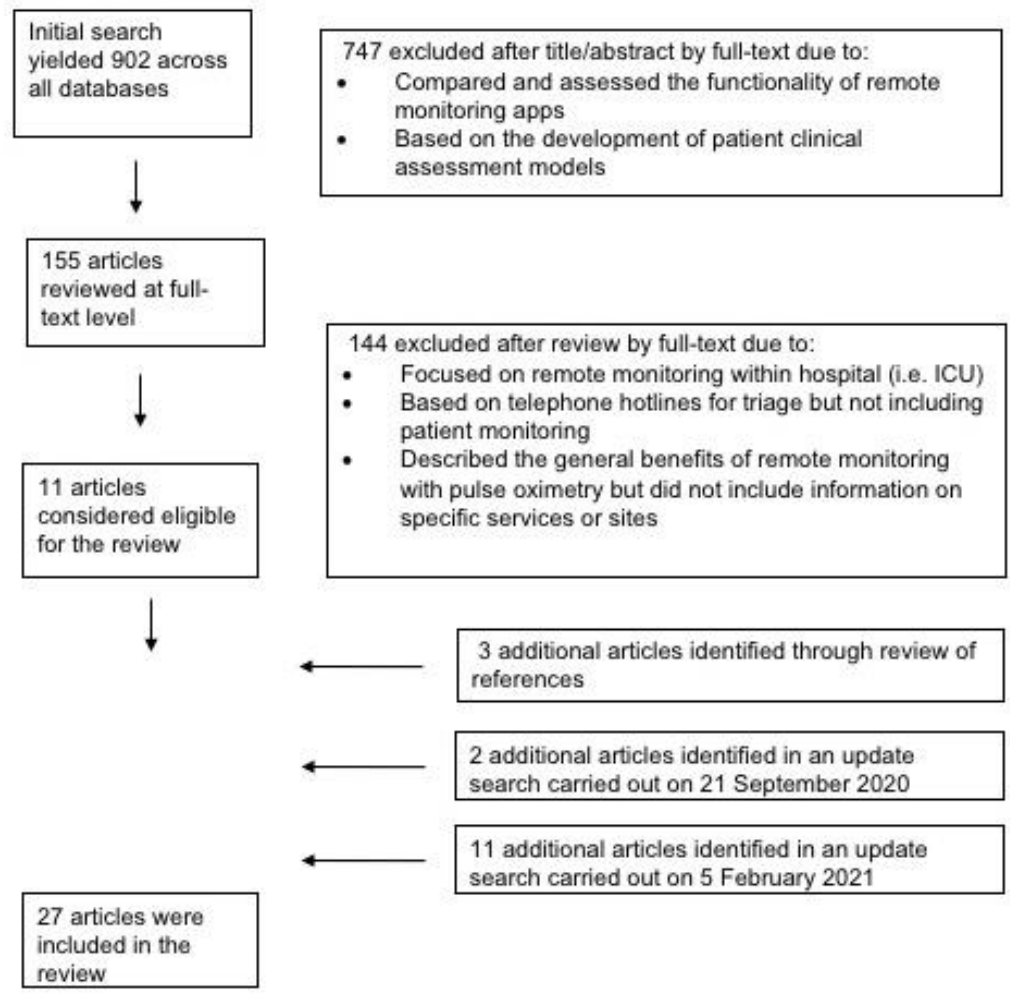

\section{Characteristics of the included remote home monitoring models}

Eleven of the remote home monitoring models were implemented in the US, nine in the UK, two in Canada, two in the Netherlands and one each in China, Ireland, Brazil and Australia. Twelve of the articles described the service, six were identified as evaluations, seven as observational studies, one as a feasibility study and one (containing the example of two models) was a news feature (with a limited description of the services). Eighteen of the examples were published in peer-reviewed journals, nine were published in the form of preprints and one was a published conference abstract. The main characteristics of the included remote home monitoring examples are summarised in Appendix 2.

\section{Aims and main designs of remote home monitoring models}

The primary aim of the remote home monitoring models was to enable the early identification of deterioration for patients self-managing COVID-19 symptoms at home (including those who had not been admitted to hospital as well as those who had been discharged). The programme theory guiding these models was that if patients were able to take the required regular observations whilst remaining at home and communicate these to the healthcare professionals responsible for their care, then cases of deterioration could be identified early and acted upon. These actions could include changing their treatment protocol, referring them to primary care or to the emergency department for assessment and potential admission to hospital. A secondary aim of the models was their use to reduce the rate of hospital infection and demand for beds in the acute care sector, where admission to hospital could be prevented for patients considered suitable to be managed at home and those who had been admitted to hospital could be discharged earlier but continue under the remote care of a medical team (a team that varied in composition depending on the model).

Most of the remote home monitoring models included in the review (23 examples) were led by teams in secondary care. Three examples were primary care led and two were led by both secondary and primary care. Thirteen of the models functioned as pre-admission 
medRxiv preprint doi: https://doi.org/10.1101/2020.10.07.20208587; this version posted March 23, 2021. The copyright holder for this preprint (which was not certified by peer review) is the author/funder, who has granted medRxiv a license to display the preprint in perpetuity.

It is made available under a CC-BY 4.0 International license .

wards, in the sense that they sought to prevent the admission of patients to hospital or to identify cases of deterioration early (so those who should be referred could be admitted to hospital with lower rates of acuity). Five of the models functioned as "step-down" wards, that is, they were designed for patients who had been admitted to hospital (including ICU) where the medical team had identified that they could be discharged and safely monitored at home until their symptoms improved. Ten models functioned as pre-admission and step-down wards, organised according to two separate pathways.

\section{Patient populations considered appropriate for remote monitoring}

Most of the models established a broad criteria for patient eligibility, defining the patient group as adult (over $18 \mathrm{yrs}$.) patients with COVID-19 symptoms (suspected and confirmed cases). Six of the models limited referrals to COVID-19 cases confirmed through testing ${ }^{62-15}$. The model described by Hutchings et al. ${ }^{6}$ excluded patients over 65 years with significant comorbidities. Shah et al. ${ }^{16}$ excluded pregnant women and only included patients with $\mathrm{SpO}_{2}$ above $92 \%$ at initial assessment. We did not find any examples targeting socially and economically disadvantaged groups (although some models included support from social workers and mental health professionals) ${ }^{4}{ }^{17}$. It is important to highlight that the size of the patient cohorts varied considerably (see Table 1 for patient numbers) and ranged from 12 patients to 6853. The models with the highest numbers of patients were implemented in the US. The comorbidities mentioned with greater frequency were hypertension, asthma and obesity.

Table 1. Main characteristics of monitored patients

\begin{tabular}{|c|c|c|c|}
\hline & $\begin{array}{l}\text { Number } \\
\text { patients }\end{array}$ & Mean age & $\begin{array}{c}\text { Most common } \\
\text { comorbidities }\end{array}$ \\
\hline Agarwal & 97 & $\begin{array}{l}\text { Inconsistencies } \\
\text { in reporting in } \\
\text { the article (48.6, } \\
43.6 \text { and } 43.8)\end{array}$ & $\begin{array}{r}\text { Asthma, } \\
\text { hypertension, } \\
\text { dyslipidemia and } \\
\text { anxiety }\end{array}$ \\
\hline Annis & 2255 & median $38^{*}$ & NS \\
\hline Grutters & 33 & 57 & NS \\
\hline Margolius & 4213 & 42 & NS \\
\hline Lam & 50 & median 44 & $\begin{array}{r}\text { hypertension, } \\
\text { malignant } \\
\text { disease }\end{array}$ \\
\hline Medina & 878 & NS & NS \\
\hline O'Keefe & 496 & 47.6 & $\begin{array}{r}\text { hypertension, } \\
\text { obesity, asthma } \\
\text { diabetes }\end{array}$ \\
\hline Shah & 77 & median 44 & $\begin{array}{r}\text { obesity and } \\
\text { hypertension }\end{array}$ \\
\hline $\mathrm{Xu}$ & 48 & median 37.5 & NS \\
\hline Hutchings & 162 & median 38 & NS \\
\hline Kricke & 6835 & $47^{* *}$ & NS \\
\hline Ford & 154 & NS & NS \\
\hline Maghrabi & 300 & 57 & Hypertension \\
\hline $\begin{array}{l}\text { Thornton1 } \\
\text { (Watford) }\end{array}$ & 1042 & NS & NS \\
\hline $\begin{array}{l}\text { Thornton2 } \\
\text { (Reading) }\end{array}$ & 244 & NS & NS \\
\hline Morgan & 2348 & $40-49$ & NS \\
\hline O'Carroll & 18 & median 48 & NS \\
\hline Bell & 192 & median 43 & NS \\
\hline Gaeta & 488 & NS & NS \\
\hline
\end{tabular}


medRxiv preprint doi: https://doi.org/10.1101/2020.10.07.20208587; this version posted March 23, 2021. The copyright holder for this preprint (which was not certified by peer review) is the author/funder, who has granted medRxiv a license to display the preprint in perpetuity.

It is made available under a CC-BY 4.0 International license .

\begin{tabular}{|l|r|r|r|}
\hline Gordon & 225 & Median 54 & NS \\
\hline Kodama & 50 & NS & NS \\
\hline Nunan & 273 & median 50.3 & NS \\
\hline Pereira & 12 (COVID- & 37.2 & $\begin{array}{r}\text { Obesity, } \\
\text { hypertension }\end{array}$ \\
\hline Silven & 55 & NS & NS \\
\hline Francis & 900 & 54.9 & $\begin{array}{r}\text { Diabetes, } \\
\text { Asthma }\end{array}$ \\
\hline $\begin{array}{l}\text { Vindrola- } \\
\text { Padros }\end{array}$ & 2084 & NS & NS \\
\hline Wilcock & 41 & 45.9 & NS \\
\hline Clarke & 908 & 54 & NS \\
\hline
\end{tabular}

${ }^{*}$ For the subset of 1496 patients who completed the programme; ${ }^{* *}$ for a subset of 6,006 who completed a survey

NS=not specified

\section{Stages of remote home monitoring}

The articles described five main stages in remote home monitoring for COVID-19: 1) referral and triage to determine eligibility, 2) onboarding of patient to remote home monitoring service (provision of information to patient and/or carer on monitoring process, mechanisms for escalation and self-care), 3) monitoring (including recording of observations, communication of the information, assessment of the information by the medical team), 4) escalation (if required), and 5) discharge from the pathway.

Patient information recorded at triage included:

- Patient demographics (age, sex, race/ethnicity, insurance type in the models in the US)

- Clinical variables (clinical signs and symptoms, medical history and medications)

- Health data for risk assessment and vital signs data (body temperature, heart rate, respiratory rate and oxygen saturation)

Three studies included some degree of detail in relation to the categorisation of patients in relation to risk ${ }^{14171819}$. O'Keefe and colleagues ${ }^{12}$ described and evaluated a risk assessment model based on age, medical history and symptom severity. This model was able to identify the need for hospitalisation in initially non-severe COVID-19 patients.

In ten of the examples included in the review, monitoring was based on patient record of observations using a paper-based system and then communicating the information to a member of the medical team by telephone (see Appendix 2). Twelve of the examples relied on the use of an online mechanism, either through an app or online form. Three examples offered patients a telephone or an app option ${ }^{20}$. Another example relied on the use of wearable sensors to continuously monitor temperature readings and transfer these to the medical team ${ }^{6}$. Twenty of the models relied on the use of pulse oximetry from the beginning of implementation, four models did not use pulse oximetry, one model added pulse oximetry three weeks after implementation and two articles indicated that the use of pulse oximetry was being considered in the near future.

Escalation was actioned depending on pre-established thresholds. Not all articles have reported thresholds for escalation and most only refer to the worsening of symptoms. Shah et al. ${ }^{16}$ indicated that patients on their remote home monitoring pathway were flagged as deteriorating if reporting $\mathrm{SpO}_{2}$ below $92 \%$ after a double reading. Xu et al. ${ }^{21}$ used a $\mathrm{SpO}_{2}$ reading of below $93 \%$ or BP less than $90 / 60 \mathrm{mmHg}$. Some of the examples included in the 
medRxiv preprint doi: https://doi.org/10.1101/2020.10.07.20208587; this version posted March 23, 2021. The copyright holder for this preprint (which was not certified by peer review) is the author/funder, who has granted medRxiv a license to display the preprint in perpetuity.

It is made available under a CC-BY 4.0 International license .

review established safety-netting options in cases when patients could not be reached via phone such as calling the police so they could visit the patient at home ${ }^{6}$.

Most patients were followed-up until their symptoms improved or the patient opted out of the pathway. Medina et al. ${ }^{13}$ reported following up patients on the step-down pathway for 7 days post-discharge from hospital and those on the pre-admission pathway for 14 days. Shah et al. ${ }^{16}$ followed-up patients on their pre-admission pathway for 7 days. Hutchings et al. ${ }^{6}$ referred patients to their GP for follow-up after discharging them from the remote home monitoring pathway.

\section{Expected outcomes of implementing remote home monitoring}

The outcomes recorded in each remote home monitoring model are listed in Appendix 2. They can be grouped in three main categories: 1) process outcomes related to the remote home monitoring pathway, 2) process outcomes related to secondary care and 3) patient outcomes (including clinical and experience). Process outcomes related to the remote home monitoring pathway included: time from swab to assessment, time to escalation and ambulance attendance/emergency activation (i.e. calling 999 or 911). Process outcomes related to secondary care included length of stay. Outcomes considered at the patient level included: emergency department attendance/reattendance, hospital admission, ICU admission, readmission, mortality, ventilation or non-invasive ventilation needs, and patient satisfaction.

\section{Impact on outcomes}

It was difficult to carry out an analysis of the impact of remote home monitoring across all examples because not all articles reported data on the same outcomes (Table 2). Mortality rates were low, admission or readmission rates ranged from 0 to $29 \%$, and ED attendance or reattendance ranged from 4 to $36 \%$. Six of the models reported data on patient feedback, with high satisfaction rates 58182223242526 .

Remote home monitoring process outcomes were only included in six of the articles, with time from swab to assessment ranging from 2 to 3.7 days ${ }^{12} 1720$ and virtual length of stay from 3.5 days to 13 days (see Table 2). Only one article presented findings on reduction in length of stay, calculated at 5 days fewer per patient ${ }^{26}$.

Table 2. Impact of remote home monitoring on selected outcomes

\begin{tabular}{|c|c|c|c|c|c|}
\hline & virtual LoS & Escalation & $\begin{array}{r}\text { ED attendance/ } \\
\text { reattendance }\end{array}$ & $\begin{array}{r}\text { Admission/ } \\
\text { readmission }\end{array}$ & Mortality \\
\hline Agarwal & 8 days (median) & $5.10 \%$ & $4.2 \%$ & 0 & NS \\
\hline Annis & NS & NS & $4.0 \%$ & $0.6 \%$ & NS \\
\hline Grutters* & 13 days (mean) & $\begin{array}{r}18 \text { patients } \\
\text { reassessed } \\
\text { in hospital }\end{array}$ & NS & $9 \%$ ** & 0 \\
\hline Margolius* & NS & NS & $7 \%$ & $1 \%$ & NS \\
\hline Lam & $\begin{array}{r}12.5 \text { days (only } \\
\text { for } 52 \% \text { of } \\
\text { patients) }\end{array}$ & $12 \%$ & NS & $8 \%$ & 0 \\
\hline Medina & NS & $10 \%$ & NS & $2 \%, 3 \%$ ** & $\begin{array}{r}9 \text { patients but } \\
\text { denominator is } \\
\text { unclear }\end{array}$ \\
\hline O'Keefe & 13.1 days & NS & NS & $7.1 \%$ & NS \\
\hline Shah & NS & $25 \%$ & $36 \%$ & $29 \%$ & $2.6 \%$ \\
\hline $\mathrm{Xu}$ & NS & NS & NS & NS & 0 \\
\hline Hutchings & $\begin{array}{r}8 \text { days (only for } \\
62 \text { of the }\end{array}$ & 5 patients & $2.5 \%$ & $1.9 \%$ & 0 \\
\hline
\end{tabular}


medRxiv preprint doi: https://doi.org/10.1101/2020.10.07.20208587; this version posted March 23, 2021. The copyright holder for this preprint (which was not certified by peer review) is the author/funder, who has granted medRxiv a license to display the preprint in perpetuity.

It is made available under a CC-BY 4.0 International license .

\begin{tabular}{|c|c|c|c|c|c|}
\hline & $\begin{array}{r}\text { patients in the } \\
\text { sample) }\end{array}$ & & & & \\
\hline Kricke & NS & NS & $7.7 \%$ & NS & NS \\
\hline Ford & NS & $\begin{array}{r}14.3 \% \\
\text { referred to } \\
\text { physician } \\
\text { review; } \\
3.9 \% \\
\text { physician to } \\
\text { patient call; } \\
2.6 \% \text { to ED } \\
\text { and admitted }\end{array}$ & $2.6 \%$ & $2.6 \%$ & NS \\
\hline Maghrabi & $\begin{array}{l}3.5 \text { days } \\
\text { (median) }\end{array}$ & 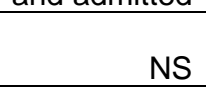 & $13 \%$ & $9 \% * *$ & $0.66 \%$ \\
\hline $\begin{array}{l}\text { Thornton1 } \\
\text { (Watford) }\end{array}$ & NS & NS & NS & NS & NS \\
\hline $\begin{array}{l}\text { Thornton2 } \\
\text { (Reading) }\end{array}$ & NS & NS & $11.9 \%$ & $7.4 \%$ & 0 \\
\hline Morgan & $\begin{array}{r}12.7 \text { days } \\
\text { (mean) }\end{array}$ & $\begin{array}{r}16.9 \% \\
\text { escalated to } \\
\text { nurse review }\end{array}$ & $7.9 \%$ & $3.4 \%$ & NS \\
\hline O'Carroll & $\begin{array}{r}12 \text { days } \\
\text { (median) }\end{array}$ & NS & NS & 4 patients & NS \\
\hline Bell & NS & NS & $16.7 \%$ & $3.6 \%$ & 0 \\
\hline Gaeta & NS & NS & $18.4 \%$ & $8.8 \%$ & $1.2 \%$ \\
\hline Gordon & unclear & NS & $4.9 \%$ & $1.3 \%$ & NS \\
\hline Kodama & NS & $26 \%$ & $6 \% * * * *$ & $2 \%^{* * * *}$ & NS \\
\hline Nunan & NS & NS & $11.4 \%$ & $7.0 \%$ & $0.4 \%$ \\
\hline Pereira & NS & NS & NS & NS & NS \\
\hline Silven & NS & NS & NS & $9 \%$ & 0 \\
\hline Francis & NS & NS & NS & $8.1 \%$ & $2.0 \%$ \\
\hline $\begin{array}{l}\text { Vindrola- } \\
\text { Padros }\end{array}$ & NS & $10.4 \%$ & $8.3 \%$ & $6.4 \%$ & $1.1 \%$ \\
\hline Wilcock & $\begin{array}{r}10.3 \text { days } \\
\text { (mean) }\end{array}$ & NS & NS & $7.3 \%$ & $1.9 \%^{* * *}$ \\
\hline Clarke & NS & NS & $5.7 \%$ & $4.4 \%$ & $3.1 \%$ \\
\hline
\end{tabular}

*included data for patients on remote home monitoring pathway, ${ }^{* *}$ refers to readmission in cases of step-down, wards, ${ }^{* * *}$ of 52 initially recruited, ${ }^{* * * *}$ these refer to very low patient numbers. LoS=length of stay, ED= emergency department, NS= not specified or not able to calculate based on data reported in the manuscript.

\section{The economic impact}

Very few of the selected studies for this rapid review provided a descriptive form of economic analysis, though some of them mentioned the potential for cost savings based on the utilisation of virtual monitoring programs for other treatments in similar settings ${ }^{1422} 26$. The study by Nunan and colleagues ${ }^{22}$ found that setting up a remote oximetry monitoring at the Royal Berkshire Hospital resulted in cost avoidance (in terms of bed days, saturation probes and staffing wages) that amounted to $£ 107,600$ per month. The amount spent per patient on remote monitoring varied by country and type of costs included in the analysis. The study from Gaeta and colleagues ${ }^{27}$ reported a total cost of $\$ 621.8 \mathrm{~K}$ (equivalent of $£ 485.0 \mathrm{~K}$ using purchasing power parity) for 621 COVID-19 patients that were monitored using outpatient telehealth follow-up in the Brooklyn Methodist Hospital. These costs included also costs of inpatient follow-up and averaged at $£ 781.0$ per monitored patient, whereas the mean cost per monitored patient reported in England varied from $£ 400$ to $£ 553$ for step-down and pre-hospital models respectively ${ }^{24}$. Some of the selected studies highlighted the fact that, during the pandemic, the intervention used existing resources and staff that were made available due to the emergency situation ${ }^{7121428}$. However, they also 
medRxiv preprint doi: https://doi.org/10.1101/2020.10.07.20208587; this version posted March 23, 2021. The copyright holder for this preprint (which was not certified by peer review) is the author/funder, who has granted medRxiv a license to display the preprint in perpetuity.

It is made available under a CC-BY 4.0 International license .

highlighted that, with the return to normal workloads in the health care system, a question of allocation of resources and sufficient staffing still remains.

\section{DISCUSSION}

In this article we have sought to make a contribution to the rapidly growing evidence-base on the use of remote home monitoring models for patients with confirmed or suspected COVID19 (see box 1 for key lessons). The review has pointed to factors that need to be taken into consideration in relation to the design of these models. Most of the models included in the study were led by secondary care but some authors argued that coordination between primary and secondary care could facilitate the implementation of remote home monitoring pathways ${ }^{5713}$. Primary care led models might be more adaptable to evolving patient and system needs and easier to replicate in contexts with limited secondary care access and capacity ${ }^{17}$. Three models integrated mental health and social care support during and after patient monitoring, highlighting a wide range of patient needs ${ }^{6} 1317$.

Box 1. Key lessons in the implementation of remote home monitoring models during the COVID-19 pandemic

- It is important to consider remote home monitoring models as an approach to maintain patients safe in the right setting.

- The use of apps for monitoring allowed the follow-up of a higher number of patients (compared to paper-based models), but some of the studies indicated that models based on telephone calls were more inclusive (i.e. including patients without internet access or technological literacy).

- Patient/carer training was identified as a key determining factor of the success of these models.

- Coordination between primary and secondary care facilitated implementation

- Primary care led models were considered, in some cases, as more adaptable to evolving patient and system needs, and easier to replicate in contexts with limited secondary care access and capacity.

- A few models integrated mental health and social care support during and after patient monitoring, highlighting a wide range of patient needs.

Despite several of the examples used apps and other types of online platforms, discussions in relation to the use of health technology were limited. The use of apps for monitoring allowed the follow-up of a higher number of patients (compared to paper-only models) but some of the studies indicated that models based on telephone calls were more inclusive (i.e. including patients without internet access or technological literacy $)^{19}$. Patient experience was captured in some of the examples we reviewed ${ }^{86}$ but the analysis was limited. An analysis of patient experience and engagement is important as the literature on the use of remote patient monitoring for other conditions has demonstrated that higher levels of patient engagement with remote patient monitoring technology are associated with better patient outcomes ${ }^{29}$.

Similarly to other reviews on remote patient monitoring in other conditions, another limitation was the lack of attention placed on the implementation of the models and the failure to identify the programme theories guiding their design, factors that acted as barriers and facilitators and the extent to which the pathways were implemented according to their original plans ${ }^{30}$. This could be due to the limited evidence on COVID-19 and the management of patients with this disease at the time of designing and implementing these models as well as the general limited use of programme theories in the design of healthcare interventions that has already been documented in the literature ${ }^{31}$.

Emerging international evidence has indicated that lower thresholds for oxygen saturation, are associated with worse patient outcomes ${ }^{2}{ }^{32}$. In the case of our review, even though some 

medRxiv preprint doi: https://doi.org/10.1101/2020.10.07.20208587; this version posted March 23,2021 . The copyright holder for this
preprint (which was not certified by peer review) is the author/funder, who has granted medRxiv a license to display the preprint in perpetuity.

It is made available under a CC-BY 4.0 International license .

authors argued that pulse oximetry identified the need for hospitalisation when using a cutoff of $92 \%{ }^{16}$, we could not reach conclusions in relation to patient safety and the degree to which remote home monitoring models can conclusively identify cases of deterioration at an earlier stage in the disease trajectory. The main reasons were lack of standardised reporting across articles in relation to these outcome measures and how these were measured, as well as the limitation that none of the articles used comparators.

Issues with using pulse oximetry were also highlighted such as: patient physiological measures needed to be recorded several times a day to correctly identify cases of deterioration, some remote home monitoring examples used standardised home pulse oximeters to avoid variability between different brands, pulse oximetry readings were made less accurate by nail polish, severe anaemia, hyperbilirubinemia, hemoglobinopathies, or poor peripheral perfusion from severe vasoconstriction or poor cardiac output ${ }^{16}{ }^{33}$. Some authors also argued that patient training was a key determining factor of the success of health information technology as it ensured readings and other observations were carried out accurately ${ }^{6}$. Remote home monitoring needed to be seen as an approach to maintain patients safely in the right setting rather than as an admission avoidance model.

Remote home monitoring for COVID-19 patients was expected to have a positive economic impact, mainly due to costs savings in staff time and PPE utilisation, avoidance of infection of frontline medical staff and reduced hospitalisations ${ }^{1421}$. However, the economic evidence in relation to these was limited. Very few of the selected studies included a simple descriptive form of economic analysis which included the cost per patient and the cost avoidances of using remote monitoring for patients with COVID-19. The selected studies have, however, raised the issue of resource allocation and funding, especially when it comes to the continuity of such programs after the first emergency situation. Most of the staff who worked on remote monitoring interventions for COVID-19 came from other services and the resources used were already existing. Yet, with the return to normal workloads, providing sufficient staff and enough resources may become a problem. Previous studies have indicated that remote monitoring in itself has contributed to increased efficiency in the use of resources (such as reduction in length of stay, increasing bed availability without compromising patient care safety, etc. $)^{1521}$. A complete economic analysis in this context could indicate if remote home monitoring for COVID-19 patients is a cost-effective intervention and could help inform accurate planning of the needed resources and staff. This economic analysis would also need to include costs and benefits beyond the actual remote home monitoring models, a reliable control group, as well as a longer follow up period.

This review has a series of limitations. The last search was carried on 5 February 2021, so any articles published after this date were not included. We have included preprints as a way to address delays produced by external review and publication. Furthermore, although we employed multiple broad search terms, it is possible that we missed articles that did not use these terms. Due to the variability in study designs and the descriptive nature of the articles we did not assess these for quality using standardised tools for assessment. However, we feel it is important to note that we found several cases of missing data and inconsistencies in the reporting of evaluations that would lead to low quality ratings.

The review pointed to several future areas of research. These could include an analysis of patient experience, beyond measures of satisfaction and the exploration of potential inequalities in patients' access to remote home monitoring models or patients' difficulties interacting with technology. Technological barriers have been reported in other studies of remote home monitoring and should not be overlooked when exploring the experiences of patients with COVID-193435. Additional attention needs to be paid to the processes used to implement these models and how these might vary based on the healthcare sector, patient population, size, wave of the pandemic and approaches used for triage, monitoring and escalation. As mentioned earlier, primary care might need to play a more central role in the 
medRxiv preprint doi: https://doi.org/10.1101/2020.10.07.20208587; this version posted March 23, 2021. The copyright holder for this preprint (which was not certified by peer review) is the author/funder, who has granted medRxiv a license to display the preprint in It is made available under a CC-BY 4.0 International license.

coordination of remote patient monitoring models, providing more holistic care for patients and reducing the demand on hospital services ${ }^{36}$. The evaluation of remote home monitoring, considering its impact on patient outcomes through the use of comparators is also required. We also need to consider the sustainability of these models during multiple epidemiological peaks, compare different approaches to remote home monitoring and assess their cost-effectiveness. 
medRxiv preprint doi: https://doi.org/10.1101/2020.10.07.20208587; this version posted March 23, 2021. The copyright holder for this preprint (which was not certified by peer review) is the author/funder, who has granted medRxiv a license to display the preprint in It is made available under a CC-BY 4.0 International license .

\section{Declaration of competing interests}

All authors have completed the ICMJE uniform disclosure form at www.icmje.org/coi_disclosure.pdf and declare: NJF, ST, TG, CSJ, CVP, MS, KS had financial support for the submitted work from NIHR (Health Services and Delivery Research, 16/138/17 - Rapid Service Evaluation Research Team; The Birmingham, RAND and Cambridge Evaluation (BRACE) Centre Team (HSDR16/138/31) and NJF is an NIHR Senior Investigator; no financial relationships with any organisations that might have an interest in the submitted work in the previous three years; no other relationships or activities that could appear to have influenced the submitted work. The views and opinions expressed therein are those of the authors and do not necessarily reflect those of the HS\&DR, NIHR, NHS or the Department of Health and Social Care.

\section{Contributor and guarantor information}

NJF, CSJ, TG, KS, MS, SMT and CVP contributed to the design of the review. MB, KS and CVP participated in the study screening, selection and data extraction. CSJ, TG and SMT acted as cross-checkers of the extracted data. NJF, MIK, AS and KK reviewed and provided feedback on the manuscript. All authors approved the final version of the manuscript. The corresponding author attests that all listed authors meet authorship criteria and that no others meeting the criteria have been omitted.

\section{Dissemination declaration}

The findings from this review will be disseminated widely, including to patient organisations.

\section{Data sharing statement}

All of the relevant data are included in the manuscript and supplementary files.

\section{Patient and public engagement statement}

Patients or the public were not involved in the design, or conduct, or reporting, or dissemination plans of our research. 
medRxiv preprint doi: https://doi.org/10.1101/2020.10.07.20208587; this version posted March 23, 2021. The copyright holder for this preprint (which was not certified by peer review) is the author/funder, who has granted medRxiv a license to display the preprint in perpetuity

It is made available under a CC-BY 4.0 International license .

\section{REFERENCES}

1. Levitan RM. Pulse Oximetry as a Biomarker for Early Identification and Hospitalization of COVID-19 Pneumonia. Academic Emergency Medicine 2020;27(8):785-86. doi: 10.1111/acem.14052

2. Goyal D. Oxygen and mortality in COVID-19 pneumonia: a comparative analysis of supplemental oxygen policies and health outcomes across 26 countries. medRxiv 2020:2020.07.03.20145763. doi: 10.1101/2020.07.03.20145763

3. NHS. Pulse oximetry to detect early deterioration of patients with COVID-19 in primary and community care settings, 2020.

4. Margolius D, Hennekes M, Yaho J, et al. On the Front (Phone) Lines: Results of a COVID-19 Hotline in Northeast Ohio. medRxiv 2020:2020.05.08.20095745. doi: 10.1101/2020.05.08.20095745

5. Thornton J. The "virtual wards" supporting patients with covid-19 in the community. BMJ : British Medical Journal (Online) 2020;369 doi: http://dx.doi.org/10.1136/bmj.m2119

6. Hutchings $\mathrm{O}$, Dearing $\mathrm{C}$, Jagers $\mathrm{D}$, et al. Virtual health care for community management of patients with COVID-19. medRxiv 2020:2020.05.11.20082396. doi: 10.1101/2020.05.11.20082396

7. Kricke G, et al. Rapid Implementation of an Outpatient Covid-19 Monitoring Program. NEJM 2020 doi: 10.1056/CAT.20.0214.

8. Annis T, Pleasants S, Hultman G, et al. Rapid implementation of a COVID-19 remote patient monitoring program. Journal of the American Medical Informatics Association 2020;27(8):1326-30. doi: 10.1093/jamia/ocaa097

9. Tricco A, et al. . Rapid reviews to strengthen health policy and systems: A Practical Guide, 2017.

10. Moher D, Liberati A, Tetzlaff J, et al. Preferred Reporting Items for Systematic Reviews and Meta-Analyses: The PRISMA Statement. PLOS Medicine 2009;6(7):e1000097. doi: 10.1371/journal.pmed.1000097

11. Gale NK, Heath G, Cameron E, et al. Using the framework method for the analysis of qualitative data in multi-disciplinary health research. BMC Medical Research Methodology 2013;13(1):117. doi: 10.1186/1471-2288-13-117

12. O'Keefe JB, Tong EJ, Taylor TH, et al. Initial Experience in Predicting the Risk of Hospitalization of 496 Outpatients with COVID-19 Using a Telemedicine Risk Assessment Tool. medRxiv 2020:2020.07.21.20159384. doi: 10.1101/2020.07.21.20159384

13. Medina M, Babiuch C, Card M, et al. Home monitoring for COVID-19. Cleve Clin J Med 2020 doi: $10.3949 /$ ccjm.87a.ccc028

14. Ford D, Harvey JB, McElligott J, et al. Leveraging Health System Telehealth and Informatics Infrastructure to Create a Continuum of Services for COVID-19 Screening, Testing, and Treatment. Journal of the American Medical Informatics Association 2020 doi: 10.1093/jamia/ocaa157

15. Carroll O, MacCann R, Reilly A, et al. Remote monitoring of oxygen saturation in individuals with COVID-19 pneumonia. European Respiratory Journal 2020;56(2):2001492. doi: 10.1183/13993003.01492-2020

16. Shah S, Majmudar K, Stein A, et al. Novel Use of Home Pulse Oximetry Monitoring in COVID-19 Patients Discharged From the Emergency Department Identifies Need for Hospitalization. Academic Emergency Medicine 2020;27(8):681-92. doi: 10.1111/acem.14053

17. Agarwal P, Mukerji G, Laur C, et al. COVIDCare@Home: Lessons from a Family Medicine Led Remote Monitoring Program. medRxiv 2020:2020.07.20.20158386. doi: $10.1101 / 2020.07 .20 .20158386$

18. Maghrabi ea. The Development and Implementation of a Virtual Discharge Ward for Patients with COVID-19 Pneumonia: Data on The First 300 Patients. 2020

19. Bell LC, Norris-Grey C, Luintel A, Bidwell G, Lanham D, Marks M, Baruah T, O'Shea L, Heightman M, Logan S. Implementation and evaluation of a COVID-19 rapid follow- 
medRxiv preprint doi: https://doi.org/10.1101/2020.10.07.20208587; this version posted March 23, 2021. The copyright holder for this preprint (which was not certified by peer review) is the author/funder, who has granted medRxiv a license to display the preprint in perpetuity.

It is made available under a CC-BY 4.0 International license .

up service for patients discharged from the emergency department. Clinical Medicine. 2021 Jan;21(1):e57.

20. Lam PW, Sehgal $P$, Andany N, et al. A virtual care program for outpatients diagnosed with COVID-19: a feasibility study. CMAJ Open 2020;8(2):E407-E13. doi: 10.9778/cmajo.20200069

21. Xu H, Huang S, Qiu C, et al. Monitoring and Management of Home-Quarantined Patients With COVID-19 Using a WeChat-Based Telemedicine System: Retrospective Cohort Study. J Med Internet Res 2020;22(7):e19514. doi: 10.2196/19514 [published Online First: 2.7.2020]

22. Nunan J, Clarke D, Malakouti A, Tannetta D, Calthrop A, Xu XH, Chan NB, Khalil R, Li W, Walden A. Triage Into the Community for COVID-19 (TICC-19) Patients PathwayService evaluation of the virtual monitoring of patients with COVID pneumonia. Acute medicine. 2020 Jan 1;19(4):183-91.

23. Wilcock J, Grafton-Clarke C, Coulson T. What is the value of community oximetry monitoring in people with SARS-CoV-2? A prospective, open-label clinical study. medRxiv. 2021 Jan 1.

24. Vindrola-Padros C, Sidhu MS, Georghiou T, Sherlaw-Johnson C, Singh KE, Tomini SM, Ellins J, Morris S, Fulop NJ. The implementation of remote home monitoring models during the COVID-19 pandemic in England. medRxiv. 2020 Jan 1.

25. Kodama R, Arora S, Anand S, Choudhary A, Weingarten J, Francesco N, Chiricolo G, Silber S, Mehta PH. Reengineering the Discharge Transition Process of COVID-19 Patients Using Telemedicine, Remote Patient Monitoring, and Around-the-Clock Remote Patient Monitoring from the Emergency Department and Inpatient Units. Telemedicine and e-Health. 2020 Dec 14.

26. Grutters LA, Majoor KI, Mattern ESK, et al. Home telemonitoring makes early hospital discharge of COVID-19 patients possible. J Am Med Inform Assoc 2020:ocaa168. doi: 10.1093/jamia/ocaa168

27. Gaeta T, Chiricolo G, Mendoza C, Vaccari N, Melville L, Melniker L, Bove J. 124 Impact of a Novel Telehealth Follow-Up Protocol for At-Risk Emergency Department Patients Discharged With Presumptive or Confirmed COVID-19. Annals of Emergency Medicine. 2020 Oct;76(4):S49.28.

28. Morgan ea. Remote monitoring of patients with COVID-19: Design, implementation and outcomes of the first 3,000 patients in COVID Watch. NEJM 2020

29. Su D, Michaud TL, Estabrooks P, et al. Diabetes Management Through Remote Patient Monitoring: The Importance of Patient Activation and Engagement with the Technology. Telemedicine and e-Health 2018;25(10):952-59. doi: 10.1089/tmj.2018.0205

30. Kew KM, Cates CJ. Home telemonitoring and remote feedback between clinic visits for asthma. Cochrane Database of Systematic Reviews 2016(8) doi: 10.1002/14651858.CD011714.pub2

31. Davidoff F, Dixon-Woods M, Leviton L, et al. Demystifying theory and its use in improvement. BMJ Quality \&amp;amp; Safety 2015;24(3):228. doi: 10.1136/bmjqs2014-003627

32. Majumdar SR, Eurich DT, Gamble J-M, et al. Oxygen Saturations Less than $92 \%$ Are Associated with Major Adverse Events in Outpatients with Pneumonia: A PopulationBased Cohort Study. Clinical Infectious Diseases 2011;52(3):325-31. doi: 10.1093/cid/ciq076

33. Luks AM, Swenson ER. Pulse Oximetry for Monitoring Patients with COVID-19 at Home. Potential Pitfalls and Practical Guidance. Annals of the American Thoracic Society 2020;17(9):1040-46. doi: 10.1513/AnnalsATS.202005-418FR

34. McGillicuddy JW, Weiland AK, Frenzel RM, et al. Patient Attitudes Toward Mobile Phone-Based Health Monitoring: Questionnaire Study Among Kidney Transplant Recipients. J Med Internet Res 2013;15(1):e6. doi: 10.2196/jmir.2284 [published Online First: 08.01.2013] 
medRxiv preprint doi: https://doi.org/10.1101/2020.10.07.20208587; this version posted March 23, 2021. The copyright holder for this preprint (which was not certified by peer review) is the author/funder, who has granted medRxiv a license to display the preprint in It is made available under a CC-BY 4.0 International license .

35. Seto E, Leonard KJ, Masino C, et al. Attitudes of Heart Failure Patients and Health care Providers towards Mobile Phone-Based Remote Monitoring. $J$ Med Internet Res 2010;12(4):e55. doi: 10.2196/jmir.1627 [published Online First: 29.11.2010]

36. Park, S. et al. Strengthening the UK primary care response to COVID-19. BMJ 2020; 370.

37. Gordon WJ, Henderson D, DeSharone A, Fisher HN, Judge J, Levine DM, MacLean L, Sousa D, Su MY, Boxer R. Remote Patient Monitoring Program for Hospital Discharged COVID-19 Patients. Applied clinical informatics. 2020 Oct;11(05):792801.

38. Motta LP, Silva PP, Borguezan BM, Amaral JL, Milagres LG, Boia MN, Ferraz MR, Mogami R, Nunes RA, de Melo PL. An emergency system for monitoring pulse oximetry, peak expiratory flow and body temperature of patients with COVID-19 at home: Development and preliminary application. medRxiv. 2020 Jan 1.

39. Silven AV, Petrus AH, Villalobos-Quesada M, Dirikgil E, Oerlemans CR, Landstra CP, Boosman $\mathrm{H}$, van Os HJ, Blanker MH, Treskes RW, Bonten TN. Telemonitoring for patients with COVID-19: recommendations for design and implementation. Journal of Medical Internet Research. 2020 Sep 2;22(9):e20953.

40. Francis NA, Stuart B, Knight M, Vancheeswaran R, Oliver C, Willcox M, Barlow A, Moore $M$. Predictors of adverse outcome in patients with suspected COVID-19 managed in a virtual hospital setting: a cohort study. medRxiv. 2020 Jan 1.

41. Clarke J, Flott K, Crespo RF, Ashrafian H, Fontana G, Benger J, Darzi A, Elkin S. Assessing the Safety of Home Oximetry for Covid-19: A multi-site retrospective observational study. medRxiv. 2020 Jan 1. 
medRxiv preprint doi: https://doi.org/10.1101/2020.10.07.20208587; this version posted March 23, 2021. The copyright holder for this preprint (which was not certified by peer review) is the author/funder, who has granted medRxiv a license to display the preprint in It is made available under a CC-BY 4.0 International license .

Appendix 1. Phased search strategies

COVID-19

AND

"virtual ward" OR "remote monitoring" OR "virtual monitoring" OR "home monitoring" OR "community monitoring" OR "early monitoring"

COVID-19 OR

AND

"virtual ward" OR "remote monitoring" OR "virtual monitoring" OR "home monitoring" OR "community monitoring" OR "early monitoring" OR "pre-hospital monitoring"

AND

"silent hypoxemia" OR "pulse oximetry"

"COVID-19"[All Fields] OR "severe acute respiratory syndrome coronavirus 2"[All Fields] OR "severe acute respiratory syndrome coronavirus 2"[All Fields] OR "2019-nCoV"[All Fields] OR "SARS-CoV-2"[All Fields] OR (("Wuhan"[All Fields] AND ("coronavirus"[MeSH Terms] OR "coronavirus"[All Fields])) AND 2020[All Fields])

AND

"virtual ward" OR "remote monitoring" OR "virtual monitoring" OR "home monitoring" OR "community monitoring" OR "early monitoring" OR "remote patient monitoring" OR "prehospital monitoring" OR “Covidom" OR "My m health" OR "GetWell Loop” [All Fields]

AND

"silent hypoxemia" OR "pulse oximetry" [All Fields] 
Appendix 2. Characteristics of the included remote home monitoring examples

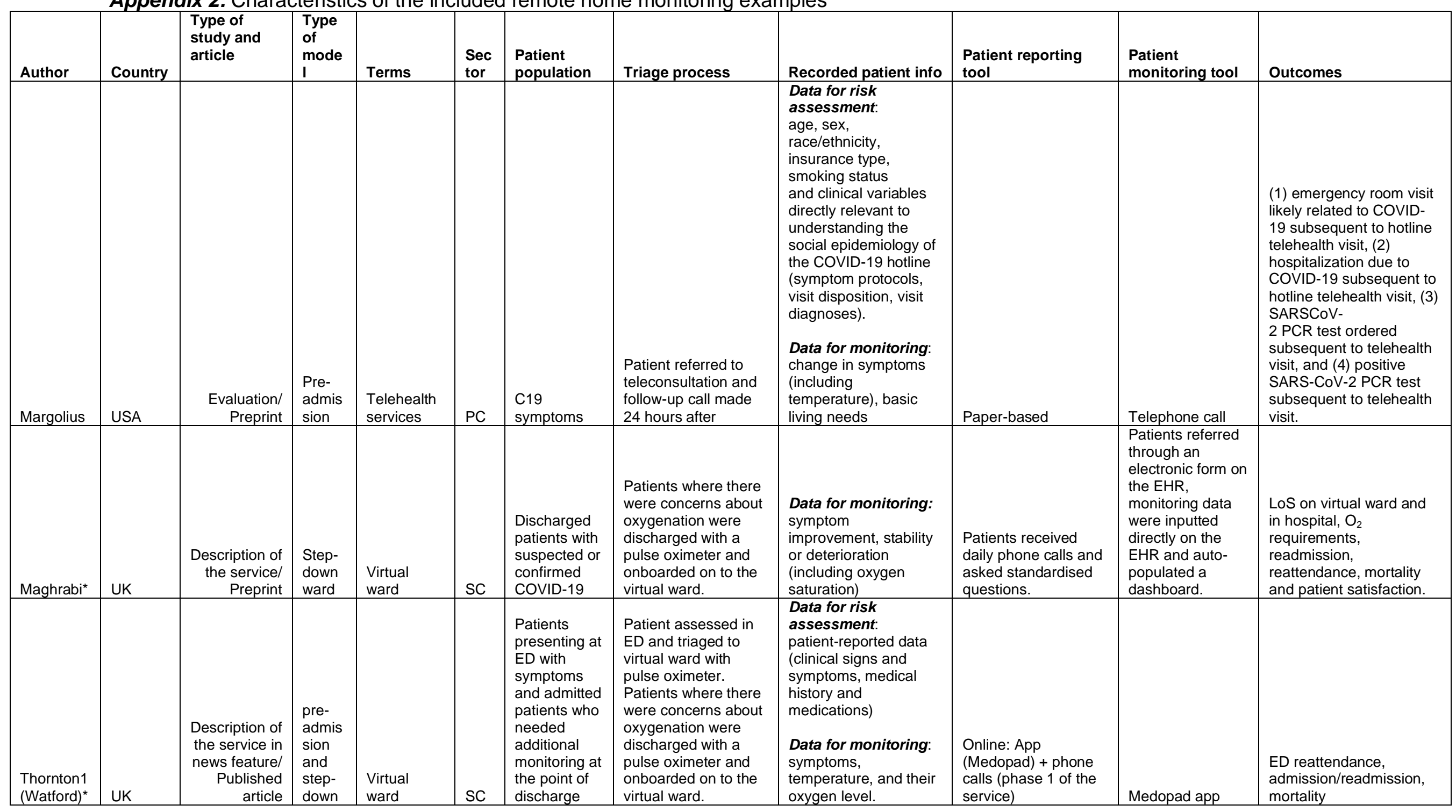




\begin{tabular}{|c|c|c|c|c|c|c|c|c|c|c|c|}
\hline $\begin{array}{l}\text { Thornton2 } \\
\text { (Reading) } \\
\text { * }\end{array}$ & UK & $\begin{array}{r}\text { Description of } \\
\text { the service in } \\
\text { news feature/ } \\
\text { Published } \\
\text { article } \\
\end{array}$ & $\begin{array}{l}\text { pre- } \\
\text { admis } \\
\text { sion } \\
\text { and } \\
\text { step- } \\
\text { down }\end{array}$ & $\begin{array}{l}\text { Virtual } \\
\text { ward }\end{array}$ & $\mathrm{SC}$ & $\begin{array}{l}\text { Patients } \\
\text { presenting at } \\
\text { ED with } \\
\text { symptoms or } \\
\text { referred from } \\
\text { primary care. } \\
\text { Also } \\
\text { included } \\
\text { admitted } \\
\text { patients who } \\
\text { needed } \\
\text { additional } \\
\text { monitoring at } \\
\text { the point of } \\
\text { discharge. } \\
\end{array}$ & $\begin{array}{l}\text { Patient assessed in } \\
\text { ED and triaged to } \\
\text { virtual ward with } \\
\text { oximeter. Patients } \\
\text { where there were } \\
\text { concerns about } \\
\text { oxygenation were } \\
\text { discharged with a } \\
\text { pulse oximeter and } \\
\text { onboarded on to the } \\
\text { virtual ward. }\end{array}$ & $\begin{array}{l}\text { Data for risk } \\
\text { assessment: } \\
\text { patient-reported data } \\
\text { (clinical signs and } \\
\text { symptoms, medical } \\
\text { history and } \\
\text { medications) } \\
\\
\text { Data for monitoring: } \\
\text { symptoms, } \\
\text { temperature, oxygen } \\
\text { saturation level. }\end{array}$ & $\begin{array}{l}\text { Paper-based (patient } \\
\text { recorded information } \\
\text { at home and reported } \\
\text { it to the medical team } \\
\text { over the phone) }\end{array}$ & $\begin{array}{l}\text { Phone call with } \\
\text { medical team. } \\
\text { Patients asked to } \\
\text { do stress test and } \\
\text { report } \mathrm{O}_{2} \text { sats } \\
\text { level }\end{array}$ & $\begin{array}{l}\text { ED reattendance, } \\
\text { admission/readmission, } \\
\text { mortality, patient } \\
\text { satisfaction }\end{array}$ \\
\hline$\underset{*}{\text { Hutchings }}$ & Australia & $\begin{array}{r}\text { Observationa } \\
\text { I study/ } \\
\text { Preprint } \\
\end{array}$ & $\begin{array}{l}\text { Pre- } \\
\text { admis } \\
\text { sion }\end{array}$ & $\begin{array}{l}\text { Virtual } \\
\text { health care, } \\
\text { remote } \\
\text { patient } \\
\text { monitoring }\end{array}$ & SC & $\begin{array}{l}\text { Patients in } \\
\text { whom C19 is } \\
\text { detected } \\
\text { (certain } \\
\text { inclusion and } \\
\text { exclusion } \\
\text { criteria } \\
\text { apply) }\end{array}$ & $\begin{array}{l}\text { Patients attend } \\
\text { COVID- } 19 \text { testing } \\
\text { clinic, those in whom } \\
\text { the virus is detected } \\
\text { are referred to the } \\
\text { virtual care centre by } \\
\text { the local public health } \\
\text { unit. The care centre } \\
\text { conducts an initial } \\
\text { assessment to } \\
\text { ascertain suitability } \\
\text { for virtual health care } \\
\text { - this is done by } \\
\text { telephone }\end{array}$ & $\begin{array}{l}\text { Data for risk } \\
\text { assessment: } \\
\text { patient-reported data } \\
\text { (clinical signs and } \\
\text { symptoms, medical } \\
\text { history and } \\
\text { medications) } \\
\text { Data for monitoring: } \\
\text { vital signs - respiratory } \\
\text { rate, oxygen } \\
\text { saturation, pulse rate } \\
\text { and temperature, } \\
\text { assessment of other } \\
\text { symptoms and signs of } \\
\text { deterioration assessed } \\
\text { by video call }\end{array}$ & $\begin{array}{l}\text { Online: Wearable } \\
\text { temperature monitor } \\
\text { provides continuous } \\
\text { temperature } \\
\text { monitoring, which } \\
\text { feed into a } \\
\text { dashboard. } \\
\text { Pulse oximeter } \\
\text { readings read directly } \\
\text { from the device. } \\
\text { Video consultations } \\
\text { used to confirm vital } \\
\text { signs collected by } \\
\text { wearable devices. }\end{array}$ & $\begin{array}{l}\text { Wearable } \\
\text { temperature } \\
\text { monitor provides } \\
\text { continuous } \\
\text { temperature } \\
\text { monitoring, which } \\
\text { feed into a } \\
\text { dashboard. } \\
\text { Patients } \\
\text { monitored three } \\
\text { times a day, } \\
\text { including a } \\
\text { videoconference } \\
\text { twice every } 24 \\
\text { hours. Video } \\
\text { consultations } \\
\text { comprised most } \\
\text { contacts with } \\
\text { telephone } \\
\text { consultations } \\
\text { making up the } \\
\text { remainder. }\end{array}$ & $\begin{array}{l}\text { Ambulance attendance, } \\
\text { ED attendance, ED } \\
\text { admission, mortality }\end{array}$ \\
\hline Kricke & USA & $\begin{array}{r}\text { Description of } \\
\text { service/ } \\
\text { Published } \\
\text { article } \\
\end{array}$ & $\begin{array}{l}\text { Pre- } \\
\text { admis } \\
\text { sion }\end{array}$ & $\begin{array}{l}\text { Home } \\
\text { monitoring, } \\
\text { outpatient } \\
\text { monitoring, } \\
\text { community } \\
\text { based } \\
\text { virtual care }\end{array}$ & SC & $\begin{array}{l}\text { Patients } \\
\text { added to the } \\
\text { registry were } \\
\text { those with } \\
\text { pending/inde } \\
\text { terminate/po } \\
\text { sitive } \\
\text { COVID-19 } \\
\text { test or } \\
\text { presumed } \\
\text { presence }\end{array}$ & $\begin{array}{l}\text { States only nurses } \\
\text { from COVID-19 triage } \\
\text { phone line, ED staff, } \\
\text { and hospital medicine } \\
\text { staff were able to add } \\
\text { patients to the } \\
\text { registry. }\end{array}$ & $\begin{array}{l}\text { Data for risk } \\
\text { assessment: } \\
\text { Evaluation of } 10 \\
\text { symptoms - used a } \\
\text { short questionnaire } \\
\text { that captured the main } \\
\text { domains of patients' } \\
\text { symptoms and } \\
\text { experiences. } \\
\text { (symptoms - cough, } \\
\text { shortness of breath, }\end{array}$ & $\begin{array}{l}\text { Online: Enrolled } \\
\text { patients with an } \\
\text { electronic health } \\
\text { record portal account } \\
\text { receive a } \\
\text { questionnaire } \\
\text { invitation where they } \\
\text { evaluate symptoms, } \\
\text { those not enrolled in } \\
\text { the patient portal (or }\end{array}$ & $\begin{array}{l}\text { They monitor and } \\
\text { stratify responses } \\
\text { to daily } \\
\text { questionnaires, } \\
\text { those with } \\
\text { concerning } \\
\text { symptoms are } \\
\text { called. Calls used } \\
\text { to evaluate } \\
\text { symptoms, } \\
\text { provide }\end{array}$ & $\begin{array}{l}\text { ED referrals (also } \\
\text { anecdotal data about } \\
\text { being provided education, } \\
\text { comfort and getting } 911 \\
\text { activation help). }\end{array}$ \\
\hline
\end{tabular}




\begin{tabular}{|c|c|c|c|c|c|c|c|c|c|c|c|}
\hline & & & & & & $\begin{array}{l}\text { based on } \\
\text { clinical } \\
\text { criteria. Later } \\
\text { began only } \\
\text { including } \\
\text { those with } \\
\text { positive } \\
\text { COVID-19 } \\
\text { test. }\end{array}$ & & $\begin{array}{l}\text { sore throat, muscle } \\
\text { aches, trouble } \\
\text { sleeping, lack of } \\
\text { energy, feeling ill, } \\
\text { fever, diarrhoea, } \\
\text { stomach pain), } \\
\text { patients were also } \\
\text { asked how many } \\
\text { analgesic/antipyretic } \\
\text { tablets they are taking, } \\
\text { symptoms of others in } \\
\text { the household, and for } \\
\text { a measured } \\
\text { temperature. } \\
\text { Data for monitoring: } \\
\text { symptoms and } \\
\text { temperature. }\end{array}$ & $\begin{array}{l}\text { who do not respond) } \\
\text { are called. }\end{array}$ & $\begin{array}{l}\text { information and } \\
\text { answer questions. }\end{array}$ & \\
\hline Annis $^{\star \star \star}$ & USA & $\begin{array}{r}\text { Evaluation/ } \\
\text { Published } \\
\text { article }\end{array}$ & $\begin{array}{l}\text { Pre- } \\
\text { admis } \\
\text { sion }\end{array}$ & $\begin{array}{l}\text { Remote } \\
\text { patient } \\
\text { monitoring, } \\
\text { telehealth }\end{array}$ & SC & $\begin{array}{l}\text { Patients with } \\
\text { confirmed or } \\
\text { suspected } \\
\text { COVID-19 }\end{array}$ & $\begin{array}{l}\text { Patients that were } \\
\text { enrolled were either } \\
\text { screened for COVID- } \\
\text { 19through virtual care } \\
\text { platforms (phone, } \\
\text { video, online) or at an } \\
\text { ED or urgent care } \\
\text { visit and referred. } \\
\text { Providers were } \\
\text { informed about the } \\
\text { programme as a care } \\
\text { option. Had a referral } \\
\text { order within } \\
\text { electronic health } \\
\text { records to gather the } \\
\text { patients' required } \\
\text { information and they } \\
\text { developed a batch } \\
\text { process to automate } \\
\text { enrolment. Then } \\
\text { patients received an } \\
\text { email with information } \\
\text { on how to activate } \\
\text { and } \\
\text { begin the programme } \\
\text { (optional). }\end{array}$ & $\begin{array}{l}\text { Data for risk } \\
\text { assessment: } \\
\text { patient-reported data } \\
\text { (clinical signs and } \\
\text { symptoms, medical } \\
\text { history and } \\
\text { medications). } \\
\text { Data for monitoring: } \\
\text { Daily check in } \\
\text { questions to } \\
\text { monitor/assess } \\
\text { symptoms, later } \\
\text { updated to include } \\
\text { question that assessed } \\
\text { pulse oximetry data. }\end{array}$ & $\begin{array}{l}\text { Online: GetWell Loop } \\
\text { - daily check in } \\
\text { questions for patients } \\
\text { to assess their } \\
\text { symptoms, patients } \\
\text { could also send } \\
\text { comments and } \\
\text { questions through } \\
\text { scrolling newsfeed. } \\
\text { Patients could also } \\
\text { call the Mhealth } \\
\text { triage line for alerts or } \\
\text { comments outside } \\
\text { 8am-5pm (before } \\
\text { they expanded the } \\
\text { workforce to include } \\
24 / 7 \text { virtual care so } \\
\text { alerts could be } \\
\text { responded to out of } \\
\text { hours). }\end{array}$ & $\begin{array}{l}\text { GetWell Loop - } \\
\text { symptom } \\
\text { monitoring } \\
\text { questions were } \\
\text { monitored - } \\
\text { concerning } \\
\text { answers routed to } \\
\text { dashboard for } \\
\text { action by member } \\
\text { of first responder } \\
\text { team. Physicians } \\
\text { would also text or } \\
\text { call patients if an } \\
\text { alert or comment } \\
\text { was } \\
\text { concerning/compli } \\
\text { cated. }\end{array}$ & $\begin{array}{l}\text { Hospital admissions, ED } \\
\text { visits. Patient satisfaction } \\
\text { data also collected. }\end{array}$ \\
\hline O'Keefe & USA & $\begin{array}{r}\text { Observationa } \\
\text { I study } \\
\text { (retrospective } \\
\text { cohort study)/ }\end{array}$ & $\begin{array}{l}\text { Pre- } \\
\text { admis } \\
\text { sion }\end{array}$ & $\begin{array}{l}\text { Telemedici } \\
\text { ne visits, } \\
\text { virtual } \\
\text { outpatient }\end{array}$ & SC & $\begin{array}{l}\text { Patients with } \\
\text { positive } \\
\text { COVID-19 } \\
\text { PCR test }\end{array}$ & $\begin{array}{l}\text { Patients with positive } \\
\text { COVID-19 PCR test } \\
\text { from screening clinics } \\
\text { or ED were referred }\end{array}$ & $\begin{array}{l}\text { Data for risk } \\
\text { assessment: } \\
\text { patient-reported data } \\
\text { (clinical signs and }\end{array}$ & $\begin{array}{l}\text { Patients received } \\
\text { regular calls }\end{array}$ & $\begin{array}{l}\text { Telephone - } \\
\text { patients received } \\
\text { regular calls, } \\
\text { different levels of }\end{array}$ & $\begin{array}{l}\text { Hospitalisation (metric: } \\
\text { days to hospitalisation). }\end{array}$ \\
\hline
\end{tabular}




\begin{tabular}{|c|c|c|c|c|c|c|c|c|c|c|c|}
\hline & & Preprint & & $\begin{array}{l}\text { manageme } \\
\mathrm{nt}, \\
\text { telephone } \\
\text { monitoring }\end{array}$ & & & $\begin{array}{l}\text { for enrolment in the } \\
\text { Virtual Outpatient } \\
\text { Management Clinic. } \\
\text { For those enrolling in } \\
\text { the virtual clinic, risk } \\
\text { assessment data } \\
\text { were obtained during } \\
\text { a scheduled } \\
\text { telemedicine } \\
\text { appointment. }\end{array}$ & $\begin{array}{l}\text { symptoms, medical } \\
\text { history and } \\
\text { medications). } \\
\text { Data for monitoring: } \\
\text { Reported symptom } \\
\text { data (including } \\
\text { temperature). }\end{array}$ & & $\begin{array}{l}\text { observation e.g. } \\
\text { frequency of calls } \\
\text { and duration, } \\
\text { based on } \\
\text { assigned risk tier. }\end{array}$ & \\
\hline Ford $^{*}$ & USA & $\begin{array}{r}\text { Description of } \\
\text { the service/ } \\
\text { Published } \\
\text { article }\end{array}$ & $\begin{array}{l}\text { Pre- } \\
\text { admis } \\
\text { sion } \\
\text { and } \\
\text { step- } \\
\text { down } \\
\text { ward } \\
\end{array}$ & $\begin{array}{l}\text { Telehealth } \\
\text { remote } \\
\text { patient } \\
\text { monitoring }\end{array}$ & $\mathrm{SC}$ & $\begin{array}{l}\text { Patients with } \\
\text { confirmed } \\
\text { COVID-19 }\end{array}$ & $\begin{array}{l}\text { Used dedicated } \\
\text { registry of COVID-19 } \\
\text { patients - populated } \\
\text { using the positive } \\
\text { diagnostic test as the } \\
\text { trigger (as well as } \\
\text { with all patients using } \\
\text { virtual urgent care for } \\
\text { COVID-19 } \\
\text { suspicions). All } \\
\text { testing submitted } \\
\text { through the site was } \\
\text { pulled into the } \\
\text { registry for potential } \\
\text { enrolment in home } \\
\text { monitoring as were } \\
\text { all positive tests } \\
\text { regardless of entry } \\
\text { point (drive up, virtual } \\
\text { urgent care, ED, } \\
\text { inpatient admission } \\
\text { or pre-op testing). } \\
\text { Nurses could enrol, } \\
\text { triage and follow } \\
\text { patients - nurses } \\
\text { contacted patients } \\
\text { who tested positive } \\
\text { and offered } \\
\text { opportunity to enrol in } \\
\text { programme. }\end{array}$ & $\begin{array}{l}\text { Data for risk } \\
\text { assessment: } \\
\text { patient-reported data } \\
\text { (clinical signs and } \\
\text { symptoms, medical } \\
\text { history and } \\
\text { medications) } \\
\text { Data for monitoring: } \\
\text { Patient reported } \\
\text { outcomes (PRO) } \\
\text { survey- derived from } \\
\text { validated community } \\
\text { acquired pneumonia } \\
\text { patient questionnaire } \\
\text { (five item survey } \\
\text { queries changes in } \\
\text { patient reported } \\
\text { dyspnea), later } \\
\text { extended to include } \\
\text { pulse oximetry (for } \\
\text { select groups inc post } \\
\text { hospitalisation) and } \\
\text { digital thermometers } \\
\text { (app also extended } \\
\text { capabilities with } \\
\text { Bluetooth pulse } \\
\text { oximeters and digital } \\
\text { thermometers). }\end{array}$ & $\begin{array}{l}\text { Online: Via patient } \\
\text { portal (Epic MyChart } \\
\text { electronic health } \\
\text { record) or app- nurse } \\
\text { managers could } \\
\text { choose which to } \\
\text { prescribe. }\end{array}$ & $\begin{array}{l}\text { Monitored } \\
\text { responses to } \\
\text { PRO through } \\
\text { portal or app, } \\
\text { nurses can reach } \\
\text { out by phone if } \\
\text { symptoms } \\
\text { worsen. }\end{array}$ & $\begin{array}{l}\text { Nurse to patient } \\
\text { encounter, referral for } \\
\text { physician review, } \\
\text { physician call, referral to } \\
\text { ED, hospitalisation. }\end{array}$ \\
\hline Agarwal $^{*}$ & Canada & $\begin{array}{r}\text { Observationa } \\
\text { I study } \\
\text { (retrospective } \\
\text { cross- } \\
\text { sectional } \\
\text { study)/ } \\
\text { Preprint } \\
\end{array}$ & $\begin{array}{l}\text { Pre- } \\
\text { admis } \\
\text { sion }\end{array}$ & $\begin{array}{l}\text { Remote } \\
\text { home } \\
\text { monitoring } \\
\text { model, } \\
\text { virtual care }\end{array}$ & PC & $\begin{array}{l}\text { Patients with } \\
\text { COVID-19 } \\
\text { (swab or } \\
\text { presumed } \\
\text { positive) felt } \\
\text { to be high- } \\
\text { risk based }\end{array}$ & $\begin{array}{l}\text { Patient attended PC } \\
\text { and was triaged to } \\
\text { low, moderate or high } \\
\text { risk using clinical } \\
\text { judgement. Follow-up } \\
\text { virtual visits were } \\
\text { booked with the } \\
\text { resident or RN every }\end{array}$ & $\begin{array}{l}\text { Data for risk } \\
\text { assessment: } \\
\text { Demographics, } \\
\text { comorbidities, COVID } \\
\text { status, risk of } \\
\text { transmission, } \\
\text { symptoms, oximeter }\end{array}$ & $\begin{array}{l}\text { Paper-based: } \\
\text { Telephone calls } \\
\text { directed by medical } \\
\text { team but patients } \\
\text { also } \\
\text { had access to a } \\
\text { dedicated on-call } \\
\text { service } 24 \text {-hours a }\end{array}$ & $\begin{array}{l}\text { Telephone or } \\
\text { video visits, } 7- \\
\text { days a week by } \\
\text { an inter- } \\
\text { professional, } \\
\text { family medicine } \\
\text { led team. Data } \\
\text { entered into EPIC }\end{array}$ & $\begin{array}{l}\text { ED attendance, } \\
\text { admission, referral to } \\
\text { social worker. }\end{array}$ \\
\hline
\end{tabular}




\begin{tabular}{|c|c|c|c|c|c|c|c|c|c|c|c|}
\hline & & & & & & $\begin{array}{l}\text { on age, } \\
\text { comorbid } \\
\text { illness and } \\
\text { respiratory } \\
\text { symptoms. }\end{array}$ & $\begin{array}{l}1-3 \text { days based on } \\
\text { risk. Program aimed } \\
\text { to follow patients } \\
\text { from } \\
\text { time of referral up to } \\
14 \text { days from } \\
\text { symptom onset. }\end{array}$ & $\begin{array}{l}\text { readings, thermometer } \\
\text { readings. } \\
\text { Data for monitoring: } \\
\text { symptoms, oximeter } \\
\text { readings, thermometer } \\
\text { readings. }\end{array}$ & $\begin{array}{l}\text { day. Pulse oximeters } \\
\text { and thermometers } \\
\text { were couriered to } \\
\text { patients. }\end{array}$ & $\begin{array}{l}\text { using a } \\
\text { standardized } \\
\text { electronic } \\
\text { flowsheet. A } \\
\text { dashboard } \\
\text { cataloguing each } \\
\text { patient in the } \\
\text { program with their } \\
\text { risk level for } \\
\text { deterioration and } \\
\text { active care issues } \\
\text { was developed to } \\
\text { facilitate daily } \\
\text { team } \\
\text { huddles. }\end{array}$ & \\
\hline $\mathrm{Xu}$ & China & $\begin{array}{r}\text { Observationa } \\
\text { I study } \\
\text { (retrospective } \\
\text { cohort study)/ } \\
\text { Published } \\
\text { article }\end{array}$ & $\begin{array}{l}\text { Pre- } \\
\text { admis } \\
\text { sion }\end{array}$ & $\begin{array}{l}\text { Telemedici } \\
\text { ne system }\end{array}$ & SC & $\begin{array}{l}\text { Confirmed or } \\
\text { suspected } \\
\text { cases of } \\
\text { COVID-19 }\end{array}$ & $\begin{array}{l}\text { Patient attended } \\
\text { hospital and was } \\
\text { assessed for } \\
\text { telemedicine system. } \\
\text { The patient was } \\
\text { given access to an } \\
\text { online telemedicine } \\
\text { form and a link to the } \\
\text { WeChat app to the } \\
\text { patient's mobile } \\
\text { phone or by email. }\end{array}$ & $\begin{array}{l}\text { Data for risk } \\
\text { assessment: } \\
\text { Demographics, clinical } \\
\text { history, clinical } \\
\text { manifestations, lab } \\
\text { tests, CT images } \\
\text { Data for monitoring: } \\
\text { changes in symptoms } \\
\text { (including } \\
\text { temperature). }\end{array}$ & $\begin{array}{l}\text { The patient was } \\
\text { required to update } \\
\text { their conditions on a } \\
\text { daily basis using the } \\
\text { telemedicine form. } \\
\text { The patient joined a } \\
\text { WeChat group to } \\
\text { receive information } \\
\text { and could set-up a } \\
\text { one-to-one chat with } \\
\text { the MDT. }\end{array}$ & $\begin{array}{l}\text { Communication } \\
\text { through } \\
\text { telemedicine form } \\
\text { and WeChat } \\
\text { group. }\end{array}$ & $\begin{array}{l}\text { ED attendance, } \\
\text { admission, mortality, } \\
\text { need for ECMO. }\end{array}$ \\
\hline Medina* & USA & $\begin{array}{r}\text { Service } \\
\text { description/ } \\
\text { Published } \\
\text { article } \\
\end{array}$ & $\begin{array}{l}\text { Pre- } \\
\text { admis } \\
\text { sion } \\
\text { and } \\
\text { step- } \\
\text { down }\end{array}$ & $\begin{array}{l}\text { Home } \\
\text { monitoring, } \\
\text { home- } \\
\text { based } \\
\text { intervention }\end{array}$ & SC & $\begin{array}{l}\text { Confirmed } \\
\text { COVID-19 } \\
\text { and risk } \\
\text { factors: risk } \\
\text { factors } \\
\text { include age } \\
\text { older than } 60 \\
\text { or younger } \\
\text { than 3, } \\
\text { active } \\
\text { immunosupp } \\
\text { ression, } \\
\text { active } \\
\text { cancer, end- } \\
\text { stage renal } \\
\text { disease on } \\
\text { dialysis, } \\
\text { diabetes, } \\
\text { hypertension } \\
\text {, coronary } \\
\text { artery } \\
\text { disease, } \\
\end{array}$ & $\begin{array}{l}\text { Patients are enrolled } \\
\text { into the home } \\
\text { monitoring program } \\
\text { after an ambulatory } \\
\text { virtual assessment } \\
\text { with a clinician, or } \\
\text { after hospital } \\
\text { discharge for COVID- } \\
\text { 19. Patients receive } \\
\text { an initial phone call } \\
\text { with instructions. } \\
\text { Patients from the } \\
\text { hospital are } \\
\text { monitored for } 7 \text { days } \\
\text { and ambulatory } \\
\text { patients for } 14 \text { days. }\end{array}$ & $\begin{array}{l}\text { Data for risk } \\
\text { assessment: } \\
\text { patient-reported data } \\
\text { (clinical signs and } \\
\text { symptoms, medical } \\
\text { history and } \\
\text { medications). } \\
\\
\text { Data for monitoring: } \\
\text { Symptoms, pulse } \\
\text { oximetry readings, } \\
\text { temperature. }\end{array}$ & $\begin{array}{l}\text { Online: Patient } \\
\text { records information } \\
\text { on the MyCare } \\
\text { Companion app. }\end{array}$ & $\begin{array}{l}\text { Daily monitoring } \\
\text { of patients } \\
\text { consists of } \\
\text { telephonic } \\
\text { outreach from a } \\
\text { registered nurse } \\
\text { or allied health } \\
\text { professional and } \\
\text { a self-monitoring } \\
\text { app (MyCare } \\
\text { Companion) that } \\
\text { allows for patient- } \\
\text { entered data. A } \\
\text { pool of nurses } \\
\text { and clinicians } \\
\text { monitor the EMR } \\
\text { registry and flag } \\
\text { symptoms that } \\
\text { are worsening. } \\
\text { After a nursing } \\
\text { assessment, a } \\
\text { patient may then }\end{array}$ & $\begin{array}{l}\text { Time to escalation, ED } \\
\text { attendance, admission, } \\
\text { mortality. }\end{array}$ \\
\hline
\end{tabular}




\begin{tabular}{|c|c|c|c|c|c|c|c|c|c|c|c|}
\hline & & & & & & $\begin{array}{l}\text { heart failure } \\
\text { with reduced } \\
\text { ejection } \\
\text { fraction, } \\
\text { chronic lung } \\
\text { disease, } \\
\text { HIV/AIDS, } \\
\text { and organ } \\
\text { transplant. }\end{array}$ & & & & $\begin{array}{l}\text { be escalated for } \\
\text { additional care } \\
\text { (virtual call or } \\
\text { referral to ED). }\end{array}$ & \\
\hline $\operatorname{Lam}^{\star *}$ & Canada & $\begin{array}{r}\text { Feasibility } \\
\text { study/ } \\
\text { Published } \\
\text { article } \\
\end{array}$ & $\begin{array}{l}\text { Pre- } \\
\text { admis } \\
\text { sion }\end{array}$ & $\begin{array}{l}\text { Virtual care } \\
\text { program }\end{array}$ & SC & $\begin{array}{l}\text { Adult } \\
\text { patients who } \\
\text { tested } \\
\text { positive for } \\
\text { COVID-19. }\end{array}$ & $\begin{array}{l}\text { Infection Prevention } \\
\text { and Control receives } \\
\text { positive test result. } \\
\text { Patient contacted via } \\
\text { phone to onboard. } \\
\text { Follow-up was } \\
\text { discontinued after } \\
\text { signs of clinical } \\
\text { improvement. }\end{array}$ & $\begin{array}{l}\text { Data for risk } \\
\text { assessment: } \\
\text { Clinical and travel } \\
\text { history, symptoms, } \\
\text { exposure. } \\
\\
\text { Data for monitoring: } \\
\text { changes in symptoms } \\
\text { (including } \\
\text { temperature). }\end{array}$ & $\begin{array}{l}\text { Online and paper- } \\
\text { based: Patients } \\
\text { record data on the } \\
\text { Ontario Telemedicine } \\
\text { Network virtual care } \\
\text { platform, but if they } \\
\text { refuse, these data } \\
\text { were collected by } \\
\text { phone. }\end{array}$ & $\begin{array}{l}\text { Stable patients } \\
\text { contacted a } \\
\text { minimum of once } \\
\text { a week, patients } \\
\text { who were } \\
\text { deemed to } \\
\text { require more } \\
\text { frequent follow-up } \\
\text { were contacted } \\
\text { up to twice a day } \\
\text { by telephone. } \\
\text { Escalation } \\
\text { arranged by the } \\
\text { service to ED. }\end{array}$ & $\begin{array}{l}\text { Time from swab } \\
\text { collection to first } \\
\text { assessment, duration of } \\
\text { virtual care, ED } \\
\text { attendance, admission, } \\
\text { ICU admission, mortality. }\end{array}$ \\
\hline Grutters* & $\begin{array}{l}\text { The } \\
\text { Netherla } \\
\text { nds }\end{array}$ & $\begin{array}{r}\text { Description of } \\
\text { service/ } \\
\text { Published } \\
\text { article } \\
\end{array}$ & $\begin{array}{l}\text { Step- } \\
\text { down }\end{array}$ & $\begin{array}{l}\text { Home } \\
\text { telemonitori } \\
\text { ng, remote } \\
\text { patient } \\
\text { monitoring }\end{array}$ & SC & $\begin{array}{l}\text { Hospitalised } \\
\text { patients } \\
\text { considered } \\
\text { appropriate } \\
\text { for discharge } \\
\text { with remote } \\
\text { monitoring. }\end{array}$ & $\begin{array}{l}\text { When patient's } \\
\text { clinical condition in } \\
\text { hospital improved, } \\
\text { they were } \\
\text { approached for the } \\
\text { home monitoring } \\
\text { service. }\end{array}$ & $\begin{array}{l}\text { Data for risk } \\
\text { assessment: } \\
\text { Clinical and travel } \\
\text { history, symptoms, } \\
\text { exposure } \\
\text { Data for monitoring: } \\
\text { Symptoms, pulse } \\
\text { oximeter and } \\
\text { temperature readings. }\end{array}$ & $\begin{array}{l}\text { Online: Patient } \\
\text { recorded data on an } \\
\text { app on a daily basis. } \\
\text { Patients were able to } \\
\text { post comments on } \\
\text { the app. }\end{array}$ & $\begin{array}{l}\text { Data from the app } \\
\text { displayed on a } \\
\text { real-time basis on } \\
\text { a dashboard. } \\
\text { Staff also made } \\
\text { calls to help with } \\
\text { oxygen therapy } \\
\text { queries and for } \\
\text { follow-ups. }\end{array}$ & $\begin{array}{l}\text { ICU admission, LoS, } \\
\text { reassessment at hospital, } \\
\text { readmission, mortality, } \\
\text { patient experience, costs. }\end{array}$ \\
\hline Shah* & USA & $\begin{array}{r}\text { Observationa } \\
\text { I study } \\
\text { (prospective } \\
\text { study)/ }\end{array}$ & $\begin{array}{l}\text { Pre- } \\
\text { admis } \\
\text { sion }\end{array}$ & $\begin{array}{l}\text { Home } \\
\text { pulse } \\
\text { oximetry } \\
\text { monitoring }\end{array}$ & $\mathrm{SC}$ & $\begin{array}{l}\text { Confirmed or } \\
\text { suspected } \\
\text { COVID-19 } \\
\text { presenting in } \\
\text { ED. }\end{array}$ & $\begin{array}{l}\text { Patient discharged } \\
\text { from ED with } \\
\text { confirmed or } \\
\text { suspected COVID-19 } \\
\text { and were given a }\end{array}$ & $\begin{array}{l}\text { Data for risk } \\
\text { assessment: } \\
\text { Demographics, } \\
\text { medical history, lab } \\
\text { tests }\end{array}$ & $\begin{array}{l}\text { Paper-based: } \\
\text { Patients recorded } \\
\text { measurements and } \\
\text { communicated these }\end{array}$ & $\begin{array}{l}\text { Patients were } \\
\text { called once a day. }\end{array}$ & $\begin{array}{l}\text { Admission, resting pulse } \\
\text { oximeter readings, LoS, } \\
\text { ICU admission, time to } \\
\text { drop, development of } \\
\text { acute respiratory distress }\end{array}$ \\
\hline
\end{tabular}




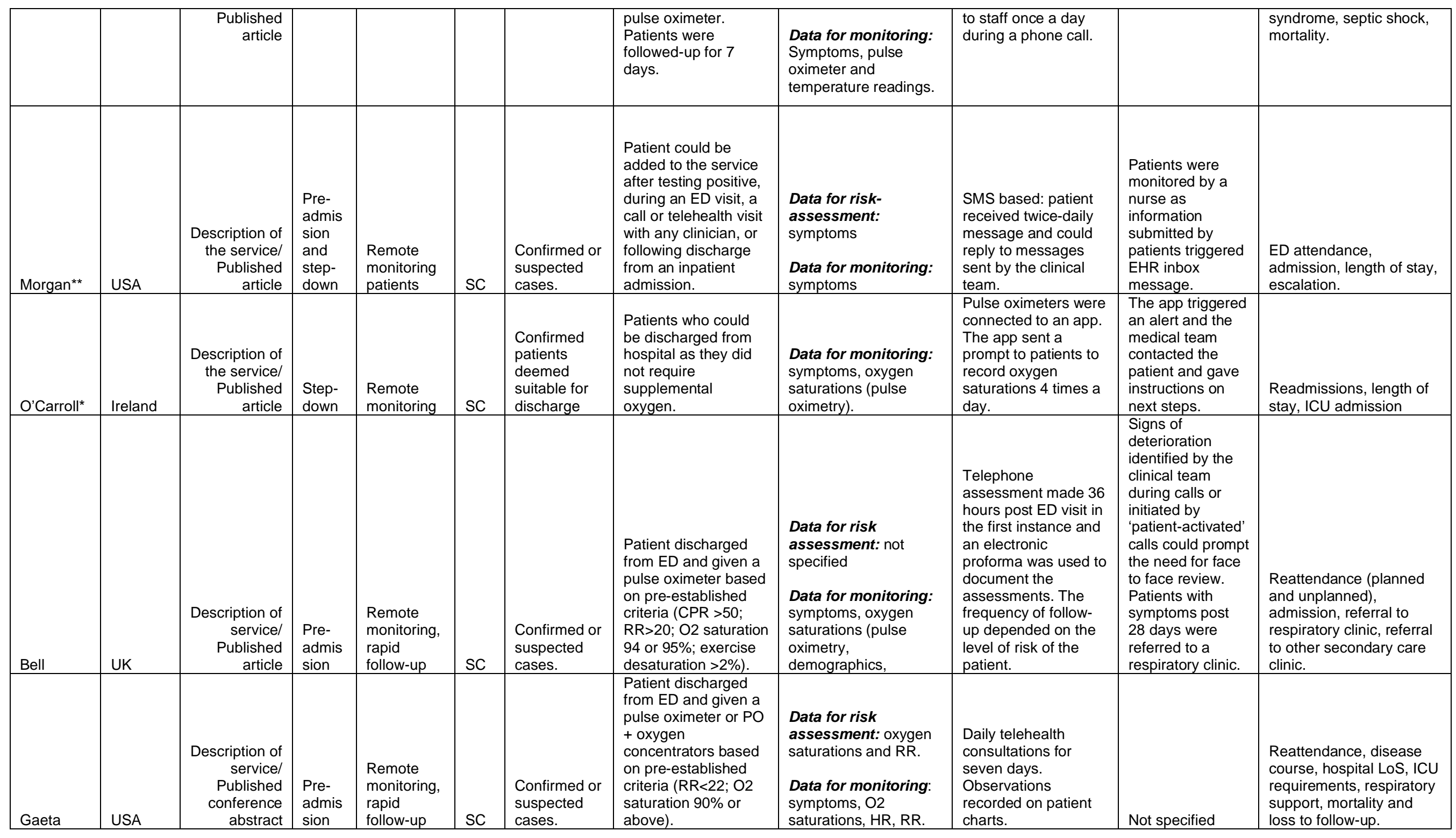




\begin{tabular}{|c|c|c|c|c|c|c|c|c|c|c|c|}
\hline Gordon & USA & $\begin{array}{r}\text { Description of } \\
\text { service/ } \\
\text { Published } \\
\text { article } \\
\end{array}$ & $\begin{array}{l}\text { Step- } \\
\text { down }\end{array}$ & $\begin{array}{l}\text { Remote } \\
\text { patient } \\
\text { monitoring }\end{array}$ & $\mathrm{SC}$ & $\begin{array}{l}\text { Confirmed or } \\
\text { suspected } \\
\text { cases. }\end{array}$ & $\begin{array}{l}\text { Patient referred to the } \\
\text { service at the time of } \\
\text { discharge. The } \\
\text { service was for adult } \\
\text { patients who did not } \\
\text { have comorbid highly } \\
\text { symptomatic non- } \\
\text { COVID-19 conditions } \\
\text { or cognitive barriers } \\
\text { to use the devices. }\end{array}$ & $\begin{array}{l}\text { Data for risk } \\
\text { assessment: not } \\
\text { specified. } \\
\text { Data for monitoring: } \\
\text { symptoms, O2 sats, } \\
\text { temperature. }\end{array}$ & $\begin{array}{l}\text { Patients used an app } \\
\text { (MyChart Care } \\
\text { Companion) to record } \\
\text { observations and } \\
\text { abnormal symptoms } \\
\text { were flagged and } \\
\text { assessed by nurses } \\
\text { leading the service. }\end{array}$ & $\begin{array}{l}\text { Symptoms that } \\
\text { worsen or no } \\
\text { response from } \\
\text { patient triggered a } \\
\text { message to the } \\
\text { the nursing team } \\
\text { who would then } \\
\text { call the patient. } \\
\text { Patient could be } \\
\text { referred to doctor } \\
\text { to determine if a } \\
\text { visit to the ED } \\
\text { was required. }\end{array}$ & $\begin{array}{l}\text { Length of stay, } \\
\text { readmission, ED } \\
\text { attendance. }\end{array}$ \\
\hline Kodama & USA & $\begin{array}{r}\text { Description of } \\
\text { service/ } \\
\text { Published } \\
\text { article } \\
\end{array}$ & $\begin{array}{l}\text { Step- } \\
\text { down }\end{array}$ & $\begin{array}{l}\text { Remote } \\
\text { patient } \\
\text { monitoring }\end{array}$ & $\mathrm{SC}$ & $\begin{array}{l}\text { Confirmed or } \\
\text { suspected } \\
\text { cases, older } \\
\text { than } 18 \\
\text { years, O2 } \\
\text { sats }<92 \% \text {, } \\
\text { confidence } \\
\text { using a PO. } \\
\end{array}$ & $\begin{array}{l}\text { Patient was identified } \\
\text { at the point of } \\
\text { discharge based on } \\
\text { pre-established } \\
\text { criteria. }\end{array}$ & $\begin{array}{l}\text { Data for risk } \\
\text { assessment: age, O2 } \\
\text { sats. } \\
\text { Data for monitoring: } \\
\text { O2 sats, HR, RR, }\end{array}$ & $\begin{array}{l}\text { Patients used an app } \\
\text { to input observations } \\
\text { and signs were } \\
\text { monitored twice a } \\
\text { day. }\end{array}$ & $\begin{array}{l}\text { Triggers for } \\
\text { escalation } \\
\text { appeared on a } \\
\text { dashboard } \\
\text { monitored by a } \\
\text { nurse. The nurse } \\
\text { also called } \\
\text { patients twice a } \\
\text { day. }\end{array}$ & $\begin{array}{l}\text { ED attendance, } \\
\text { admission. }\end{array}$ \\
\hline Nunan & UK & $\begin{array}{r}\text { Evaluation/ } \\
\text { Published } \\
\text { article }\end{array}$ & $\begin{array}{l}\text { Pre- } \\
\text { admis } \\
\text { sion } \\
\text { and } \\
\text { step- } \\
\text { down }\end{array}$ & $\begin{array}{l}\text { Virtual } \\
\text { monitoring, } \\
\text { virtual ward }\end{array}$ & $\mathrm{SC}$ & $\begin{array}{l}\text { Confirmed or } \\
\text { suspected } \\
\text { cases. }\end{array}$ & $\begin{array}{l}\text { Patient was triaged } \\
\text { into one of three } \\
\text { groups based on } \mathrm{O} 2 \\
\text { sats. Those with } \mathrm{O} 2 \\
\text { sat }>94 \% \text { could be } \\
\text { referred to virtual } \\
\text { ward. Some patients } \\
\text { referred after } \\
\text { discharge and others } \\
\text { prior to admission. } \\
\text { Patient was given a } \\
\text { PO and information. }\end{array}$ & $\begin{array}{l}\text { Data for risk } \\
\text { assessment: } \mathrm{O} 2 \text { sats, } \\
\text { symptoms, imaging } \\
\text { Data for monitoring: }\end{array}$ & $\begin{array}{l}\text { PA called patients on } \\
\text { a daily basis going } \\
\text { through a script of } \\
\text { questions about their } \\
\text { symptoms. }\end{array}$ & $\begin{array}{l}\text { When the clinical } \\
\text { team identified a } \\
\text { case of } \\
\text { deterioration the } \\
\text { patient could be } \\
\text { asked to call } \\
\text { emergency } \\
\text { services or attend } \\
\text { ED. }\end{array}$ & $\begin{array}{l}\text { ED attendance, } \\
\text { admission, ICU } \\
\text { admission, mortality, } \\
\text { costs. }\end{array}$ \\
\hline Pereira & Brazil & $\begin{array}{l}\text { Evaluation/ } \\
\text { Preprint }\end{array}$ & $\begin{array}{l}\text { Pre- } \\
\text { admis } \\
\text { sion }\end{array}$ & $\begin{array}{l}\text { Remote } \\
\text { monitoring }\end{array}$ & $\mathrm{SC}$ & $\begin{array}{l}\text { Confirmed or } \\
\text { suspected } \\
\text { cases + non- } \\
\text { COVID-19 } \\
\text { control group }\end{array}$ & Not specified & $\begin{array}{l}\text { Data for risk } \\
\text { assessment: not } \\
\text { specified } \\
\text { Data for monitoring: } \\
\text { O2 sats, BPM, } \\
\text { temperature, PEF. }\end{array}$ & $\begin{array}{l}\text { Patient asked to input } \\
\text { observations into an } \\
\text { app as well as keep a } \\
\text { paper diary. } \\
\text { Measurements are } \\
\text { taken twice daily. }\end{array}$ & $\begin{array}{l}\text { The clinical team } \\
\text { can monitor } \\
\text { patient } \\
\text { observations on a } \\
\text { dashboard }\end{array}$ & $\begin{array}{l}\text { Indicators of } \\
\text { deterioration. }\end{array}$ \\
\hline Silven & $\begin{array}{l}\text { Netherla } \\
\text { nds }\end{array}$ & $\begin{array}{r}\text { Description of } \\
\text { the } \\
\text { service/Publi } \\
\text { shed article } \\
\end{array}$ & $\begin{array}{l}\text { Pre- } \\
\text { admis } \\
\text { sion } \\
\text { and } \\
\text { step- } \\
\text { down }\end{array}$ & $\begin{array}{l}\text { Telemonito } \\
\text { ring }\end{array}$ & $\mathrm{SC}$ & $\begin{array}{l}\text { Confirmed or } \\
\text { suspected } \\
\text { cases } \\
\text { presenting in } \\
\text { the ED or } \\
\text { after } \\
\text { discharge. }\end{array}$ & $\begin{array}{l}\text { Patients with mild or } \\
\text { moderate symptoms } \\
\text { were identified in the } \\
\text { ED and onboarded to } \\
\text { the service. Patients } \\
\text { admitted to COVID- } \\
19 \text { ward who were }\end{array}$ & $\begin{array}{l}\text { Data for monitoring: } \\
\text { O2 sats, BP, } \\
\text { temperature, HR, RR }\end{array}$ & $\begin{array}{l}\text { In the initial stages of } \\
\text { implementation } \\
\text { patients kept a record } \\
\text { of their observations } \\
\text { and these were } \\
\text { added manually by th } \\
\text { clinical team to their }\end{array}$ & $\begin{array}{l}\text { A physician of PA } \\
\text { carried out daily } \\
\text { video } \\
\text { consultations to } \\
\text { monitor progress. }\end{array}$ & Admission, mortality \\
\hline
\end{tabular}




\begin{tabular}{|c|c|c|c|c|c|c|c|c|c|c|c|}
\hline & & & & & & $\begin{array}{l}\text { Over } 18 \\
\text { years, in } \\
\text { possession } \\
\text { of } \\
\text { smartphone } \\
+ \text { internet, } \\
\text { able to } \\
\text { communicat } \\
\text { e through } \\
\text { phone. }\end{array}$ & $\begin{array}{l}\text { eligible for discharge } \\
\text { could also be } \\
\text { onboarded. Patients } \\
\text { were given a COVID } \\
\text { Box containing: PO, } \\
\text { BP monitor, } \\
\text { thermometer, } \\
\text { information. }\end{array}$ & & $\begin{array}{l}\text { patient chart. In a } \\
\text { later stage, patients } \\
\text { used an app to record } \\
\text { their observations } \\
\text { and these were } \\
\text { transmitted } \\
\text { automatically to the } \\
\text { patient's electronic } \\
\text { chart. }\end{array}$ & & \\
\hline Francis & UK & $\begin{array}{r}\text { Cohort study/ } \\
\text { Preprint } \\
\end{array}$ & $\begin{array}{l}\text { Pre- } \\
\text { admis } \\
\text { sion } \\
\text { and } \\
\text { step- } \\
\text { down }\end{array}$ & $\begin{array}{l}\text { Virtual } \\
\text { hospital } \\
\text { remote } \\
\text { assessmen } \\
\mathrm{t}\end{array}$ & SC & $\begin{array}{l}\text { Confirmed or } \\
\text { suspected } \\
\text { cases } \\
\text { presenting in } \\
\text { the ED or } \\
\text { after } \\
\text { discharge. }\end{array}$ & $\begin{array}{l}\text { Patients in the ED or } \\
\text { at the point of } \\
\text { discharge were } \\
\text { assessed for } \\
\text { suitability for the } \\
\text { service. Patients } \\
\text { were triaged based } \\
\text { on risk. }\end{array}$ & $\begin{array}{l}\text { Data for risk } \\
\text { assessment: not } \\
\text { included in preprint. } \\
\\
\text { Data for monitoring: } \\
\text { O2 sats, BP, } \\
\text { temperature }\end{array}$ & $\begin{array}{l}\text { Patients were asked } \\
\text { to record their } \\
\text { symptoms and } \\
\text { observations on } \\
\text { paper. }\end{array}$ & $\begin{array}{l}\text { A member of the } \\
\text { clinical team } \\
\text { called patients } \\
\text { regularly to } \\
\text { monitor their } \\
\text { symptoms and } \\
\text { identify any signs } \\
\text { of deterioration. }\end{array}$ & $\begin{array}{l}\text { Admission, mortality, } \\
\text { predictors of adverse } \\
\text { outcomes. }\end{array}$ \\
\hline $\begin{array}{l}\text { Vindrola- } \\
\text { Padros }\end{array}$ & UK & $\begin{array}{r}\text { Service } \\
\text { evaluation/ } \\
\text { Preprint }\end{array}$ & $\begin{array}{l}\text { Pre- } \\
\text { admis } \\
\text { sion } \\
\text { and } \\
\text { step- } \\
\text { down }\end{array}$ & $\begin{array}{l}\text { Virtual } \\
\text { ward }\end{array}$ & $\begin{array}{l}\text { SC } \\
\text { and } \\
\text { PC }\end{array}$ & $\begin{array}{l}\text { Confirmed or } \\
\text { suspected } \\
\text { cases } \\
\text { presenting in } \\
\text { the ED or } \\
\text { after } \\
\text { discharge. }\end{array}$ & $\begin{array}{l}\text { The patient was } \\
\text { triaged } \\
\text { through emergency } \\
\text { telephone numbers, } \\
\text { GP practice, or ED. } \\
\text { Some were also } \\
\text { triaged at the point of } \\
\text { discharge. }\end{array}$ & $\begin{array}{l}\text { Data for risk } \\
\text { assessment: not } \\
\text { included in preprint. } \\
\\
\text { Data for monitoring: } \\
\text { symptoms, O2 sats, } \\
\text { heart rate, temperature } \\
\text { and } \\
\text { blood oxygen levels. }\end{array}$ & $\begin{array}{l}\text { The patient was given } \\
\text { a pulse oximeter, } \\
\text { patient information } \\
\text { (including escalation } \\
\text { warning signs and } \\
\text { what to do) and a } \\
\text { mechanism for } \\
\text { recording } \\
\text { observations } \\
\text { regularly } \\
\text { (app or paper diary). }\end{array}$ & $\begin{array}{l}\text { The patient } \\
\text { received regular } \\
\text { monitoring calls } \\
\text { from staff } \\
\text { capturing } \\
\text { changes in } \\
\text { symptoms. The } \\
\text { sites using apps } \\
\text { for patient } \\
\text { monitoring } \\
\text { triggered alerts if } \\
\text { symptoms } \\
\text { pointed to } \\
\text { deterioration. }\end{array}$ & $\begin{array}{l}\text { Ventilation, mortality, } \\
\text { reattendance to ED, } \\
\text { admission, ICU } \\
\text { admission, call } \\
\text { emergency services }\end{array}$ \\
\hline Wilcock & UK & $\begin{array}{r}\text { Prospective } \\
\text { study/ } \\
\text { Preprint }\end{array}$ & $\begin{array}{l}\text { Pre- } \\
\text { admis } \\
\text { sion }\end{array}$ & $\begin{array}{l}\text { Community } \\
\text { oximetry } \\
\text { monitoring }\end{array}$ & PC & $\begin{array}{l}\text { Confirmed } \\
\text { case and not } \\
\text { living in a } \\
\text { care facility. }\end{array}$ & $\begin{array}{l}\text { After a positive test } \\
\text { result, the patient } \\
\text { was invited to the } \\
\text { service and sent a } \\
\text { PO, instructions and } \\
\text { diary. }\end{array}$ & $\begin{array}{l}\text { Data for risk } \\
\text { assessment: not } \\
\text { included in preprint. } \\
\text { Data for monitoring: } \\
\text { symptoms, O2 sats, } \\
\text { degree of } \\
\text { breathlessness, Roth } \\
\text { score. }\end{array}$ & $\begin{array}{l}\text { Patients recorded } \\
\text { their symptoms and } \\
\text { O2 sats twice a day } \\
\text { on paper. }\end{array}$ & $\begin{array}{l}\text { The patient } \\
\text { received regular } \\
\text { monitoring calls } \\
\text { from staff } \\
\text { capturing } \\
\text { changes in } \\
\text { symptoms. }\end{array}$ & Deterioration, admission. \\
\hline Clarke & UK & $\begin{array}{r}\text { Evaluation/ } \\
\text { published } \\
\text { article } \\
\end{array}$ & $\begin{array}{l}\text { Pre- } \\
\text { admis } \\
\text { sion } \\
\text { and } \\
\text { step- } \\
\text { down }\end{array}$ & $\begin{array}{l}\text { Home } \\
\text { oximetry }\end{array}$ & $\begin{array}{l}\mathrm{SC} \\
\text { and } \\
\mathrm{PC}\end{array}$ & $\begin{array}{l}\text { Confirmed or } \\
\text { suspected } \\
\text { cases } \\
\text { presenting in } \\
\text { the ED, } \\
\text { primary care } \\
\end{array}$ & Not specified & Not specified & Not specified & Not specified & $\begin{array}{l}\text { ED attendance, } \\
\text { admission, mortality }\end{array}$ \\
\hline
\end{tabular}




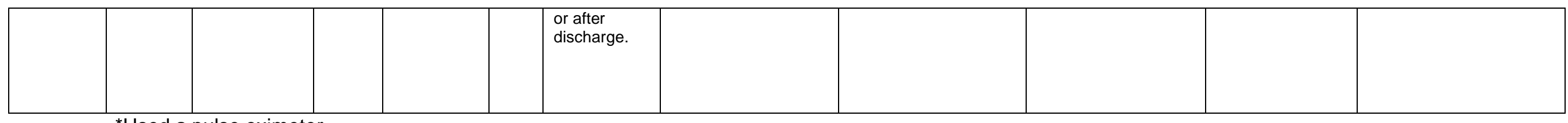

*Used a pulse oximeter

**Did not use pulse oximetry in the main model described in the article but flagged the launching of a companion programme or incorporating pulse oximetry

and escalation based on oxygen saturation at a later date.

${ }^{* * *}$ Pulse oximetry added three weeks after implementation

$\mathrm{SC}=$ secondary care

$\mathrm{PC}=$ primary care

$\mathrm{HR}=$ heart rate

$\mathrm{RR}=$ respiration rate

$\mathrm{PO}=$ pulse oximetry 